\title{
Distribution of Credit Risk among Providers of Mortgages to Lower-Income and Minority Homebuyers
}

Glenn B. Canner, Wayne Passmore, and Brian J. Surette, of the Board's Division of Research and Statistics, prepared this article. John L. Gibbons, Lisa Kirch, and Gerald W. Talley provided research assistance.

The financial institutions that bear the credit risk in mortgage lending are critical because without such participants, mortgages cannot be made. Once an institution agrees to assume the risk that a borrower will not repay a loan as scheduled, the other participants in the mortgage process-originators, funders, and purchasers - are readily available. The bearing of credit risk is an ongoing concern of the mortgage market and the government, and a variety of institutions have evolved for that purpose. The performance of these institutions in taking on credit risk has important public policy implications because home ownership, particularly within lower-income and minority communities, is a well-established national goal and is of intense public interest.

Assessing the performance of mortgage market participants in accepting credit risk is not straightforward for several reasons-lack of data, uncertainties about the most appropriate criteria for assessing performance, and the influence of government subsidies and regulations. The diversity of the participants' goals and strategies also complicates the task: The government mortgage insurers that account for most of the risk-bearing activity in the government mortgage system are nonprofit and accept nearly all the credit risk of the mortgages they insure; the mortgage originators, insurers, and purchasers that make up the conventional mortgage system are profit-seeking and generally act to spread the risk throughout the system.

In an earlier study we assessed the performance of the major participants in the market for home purchase mortgages by examining the distribution of the mortgage credit risk borne by these institutions. ${ }^{1}$ For

1. Glenn B. Canner and Wayne Passmore, "Credit Risk and the Provision of Mortgages to Lower-Income and Minority Homebuyers," Federal Reserve Bulletin, vol. 81 (November 1995), pp. 989-1016. that analysis we combined 1994 data on mortgages collected pursuant to the Home Mortgage Disclosure Act (HMDA) with 1994 data on private mortgage insurance (PMI) activity made available by private mortgage insurers. With that unique database we obtained rough measures of the amount of credit risk that the major participants bore and the distribution of that risk across institutions by the income and racial or ethnic characteristics of the borrowers and their neighborhoods. We found that the largest government insurer, the FHA, was the most involved with lower-income and minority homebuyers, as measured by both portfolio share (the proportion of an institution's own mortgage portfolio extended to these groups) and market share (the proportion of all mortgages extended to these groups for which an institution bears the credit risk). Depository institutions generally had higher portfolio and market shares than the two for-profit government-sponsored enterprises that are active in the secondary market, the Federal National Mortgage Association (Fannie Mae) and the Federal Home Loan Mortgage Corporation (Freddie Mac).

In this article we revisit the issue of who bears the credit risk associated with mortgage lending using 1995 data and refined estimates of the amount of mortgage credit risk borne by market participants. ${ }^{2}$ In our earlier analysis we measured credit risk in terms of the number of mortgages held or insured; here we go beyond looking at numbers or simple dollar amounts of mortgages held or insured and instead measure risk in terms of the dollar losses that could be expected on the basis of historical experience.

2. Unless otherwise noted, the focus of this article is mortgages approved during the first ten months of 1995 for the purchase of owner-occupied, single-family homes located in metropolitan statistical areas. Mortgages originated in the final two months of 1995 were excluded from analysis because the lenders that originated those loans may not have had the opportunity to sell them by year-end, when HMDA data must be reported. Because of the public-interest focus on lower-income and minority borrowers and neighborhoods, we present results for only FHA-eligible mortgages (that is, mortgages within the size limits for FHA-backed single-family loans). 
Institutions' expected dollar losses are determined primarily by the distribution of loan-to-value ratios within their mortgage portfolios: Higher ratios are associated with higher mortgage default probabilities and loss severity rates. Data on these aspects of mortgage lending are not reported under HMDA and are not readily available elsewhere; we obtained the information in a variety of ways, including discussions with industry participants and modeling based on preliminary data from the Federal Reserve's 1995 Survey of Consumer Finances.

Who bears the credit risk for mortgage lending to lower-income borrowers, black or Hispanic borrowers, lower-income neighborhoods, and minority neighborhoods, and how is that risk distributed? The findings based on our refined estimates of credit risk are in accord with our earlier results: In terms of market share, the FHA, the largest institution in the government mortgage system, outperforms all other institutions or types of institutions. It is the major bearer of credit risk for these groups. For example, the FHA backed about one-third of the dollar amount of mortgages extended in 1995 to lower-income borrowers but assumed nearly twothirds of the credit risk associated with lending to that group.

The market shares of the conventional mortgage system are not only small relative to the amount borne by government institutions; they are also broadly distributed across the major types of institutions in the system. No single institution or set of institutions stands out as a principal bearer of credit risk for the conventional mortgages extended to these borrowers.

The FHA also has a high portfolio share for lending to lower-income or minority borrowers and neighborhoods relative to the participants in the conventional mortgage system. However, some profit-seeking portfolio lenders devote a large share of their portfolio risk to lower-income borrowers and neighborhoods. These lenders-commercial banks, savings associations, and mortgage bankshave low-income portfolio shares similar to the FHA's, although their market shares are only slightly larger than those of others in the conventional mortgage system.

\section{THE MANAGEMENT}

\section{OF MORTGAGE CREDIT RISK}

The credit risk associated with mortgage lending is managed in a variety of ways, mainly by the use of underwriting standards and the sharing of risk among participants in the mortgage market, including borrowers. Because different groups of borrowers have different credit characteristics, the risk-management approach taken may affect the distribution of mortgage borrowers across income groups, race and ethnic categories, and neighborhoods.

Requiring borrowers to meet certain underwriting standards is the most important step lenders take to manage mortgage credit risk. In assessing the possibility that a prospective borrower may default on a mortgage, lenders evaluate both ability and willingness to repay the loan. They look at sources of income, debt-payment-to-income ratios, assets, employment history, and prospects for income growth. They also review the applicant's credit history and estimate the value of the property for which the mortgage is being sought.

Varying the price of credit by charging riskier borrowers higher interest rates is another means of managing credit risk. Lenders know, for example, that the probability of default, as well as the extent of the loss resulting from default, is strongly related to the loan-to-value ratio of the mortgage: The higher the ratio, the greater the likelihood of default and the larger the potential loss. ${ }^{3}$ To compensate for greater risk, lenders may require a borrower who takes out a mortgage having a high loan-to-value ratio to pay a higher interest rate (or, more often, to purchase mortgage insurance, which raises the effective interest rate). They may also price the mortgage according to other characteristics that may influence its riskiness; for example, they may charge higher interest rates on longer-term loans.

The sharing of credit risk is common within the home mortgage industry. First and foremost, lenders share risk with the borrower by requiring the borrower to make a down payment toward the purchase of the home. The larger the borrower's equity stake, the more the value of the home exceeds the loan balance, providing the lender with a greater cushion in case of default.

Credit risk is also shared among institutional participants in the mortgage market. For example, lenders usually require a borrower to purchase mortgage insurance from a public or private mortgage insurer if the down payment is less than 20 percent of the

3. Robert B. Avery, Raphael W. Bostic, Paul S. Calem, and Glenn B. Canner, "Credit Risk, Credit Scoring, and the Performance of Home Mortgages," Federal Reserve Bulletin, vol. 82 (July 1996), pp. 621-48. 
home's appraised value. ${ }^{4}$ Lenders also often sell mortgages in the secondary market under terms that relieve themselves of the credit risk associated with the mortgage (that is, the secondary-market institution has no recourse to the seller in the event of default).

Credit risk can also be managed by influencing the probability of default and the extent of losses associated with default. Lenders use a variety of riskmanagement techniques to encourage timely repayment. For example, they may require a prospective borrower to receive credit counseling or homebuyer education before taking out a mortgage and may work more aggressively with a borrower who becomes delinquent. To lower the losses associated with default, lenders may encourage a seriously delinquent borrower to sell the home before foreclosure (a so-called short sale), thereby avoiding the legal expenses and other costs associated with the oftenlengthy foreclosure process. Other methods of loss management include allowing delinquent borrowers to defer payments until their financial circumstances improve and modifying loan agreements. ${ }^{5}$

\section{THE MAJOR PARTICIPANTS \\ IN THE MORTGAGE MARKET}

During the past sixty years, the Congress has created public institutions - and has both granted advantages to and imposed restrictions on private institutions- to influence underwriting standards and other aspects of mortgage lending and, thus, the level and composition of mortgage activity. In recent years, congressional actions have focused on encouraging the provision of mortgage credit to lower-income and minority homebuyers and to those seeking to purchase homes in lower-income neighborhoods and central cities. These actions influence the distribution of credit risk among the participants in the mortgage market.

4. Some lenders extend low-down-payment mortgages without insurance but charge higher interest rates or have the borrower take out a second mortgage (usually equal to 10 percent of the home's appraised value) at a higher interest rate than the first mortgage (usually equal to 80 percent of the home's value), thus effectively providing the mortgage insurance themselves. In addition, some lenders provide low-down-payment mortgages without requiring mortgage insurance as part of their efforts to comply with the Community Reinvestment Act.

5. For a discussion of alternatives to foreclosure, see U.S. Department of Housing and Urban Development, "Providing Alternatives to Mortgage Foreclosure: A Report to Congress," March 1996; and Brent W. Ambrose and Charles A. Capone, Jr., "Cost-Benefit Analysis of Single-Family Foreclosure Alternatives," The Journal of Real Estate Finance and Economics, vol. 13 (September 1996), pp. 10520. Also see the 1995 annual reports of Fannie Mae and Freddie Mac.

\section{The Nonprofit Government Mortgage System}

The Congress has established nonprofit government institutions to promote home ownership among specific groups and in the population at large. Of the nonprofit government institutions, the FHA and the VA have by far the largest home loan programs. Their missions are to promote home ownership by insuring mortgages extended, respectively, to lower- and moderate-income homebuyers and to veterans. ${ }^{6}$ Subsidization by the federal government helps these agencies achieve their goals. ${ }^{7}$ The FHA plays a larger role in the mortgage market than the VA.

The FHA's activity is limited by the Congress in several ways: by size limits on the mortgages that it can insure, by restrictions on its ability to change insurance premiums, and by limits on the aggregate amount of insurance that it may write each year. The FHA relies on the insurance premiums paid by lowerrisk borrowers to cross-subsidize the costs imposed by higher-risk borrowers. ${ }^{8}$ Consequently, because private mortgage insurance may cost less, lower-risk borrowers who qualify for privately insured loans tend not to use FHA programs. ${ }^{9}$

A higher proportion of lower-income borrowers than of higher-income borrowers choose mortgages insured by the FHA or the VA. Under these programs, prospective borrowers can qualify for credit with more debt relative to income, with smaller down payments, and with weaker credit histories because the underwriting standards of the FHA and the VA are generally less strict than those used by private mortgage insurers. Many families with lower incomes need the more relaxed underwriting guidelines to qualify for mortgages because they tend to carry relatively higher loads of nonhousing debt, to have fewer assets to draw on when making down payments

6. For a discussion of the FHA and its influence in the housing market, see U.S. Department of Housing and Urban Development, Office of Policy Development and Research, "An Analysis of FHA's Single-Family Insurance Program," October 1995; and General Accounting Office, "Homeownership: FHA's Role in Helping People Obtain Home Mortgages" (GAO/RCED-96-123), August 13, 1996.

7. With respect to its largest single-family mortgage insurance program, the FHA's subsidy primarily takes the form of relief from the need to earn a private market rate of return for shareholders rather than a direct government appropriation.

8. A question arises as to why private mortgage insurers do not "cherry pick" more of the FHA's least risky borrowers, who pay higher premiums than should, in principle, be available in the private market. Among the possible explanations are state regulations limiting the ability of PMI companies to insure mortgages having loan-tovalue ratios above 97 percent, the specialization of some mortgage lenders in FHA loans, and borrowers' preferences to finance their home purchases with government-backed loans.

9. See General Accounting Office, "Homeownership: FHA's Role in Helping People Obtain Home Mortgages." 
and paying closing costs, and to have histories of credit problems or no credit histories at all. At the same time, upper-income borrowers tend to seek mortgages that exceed the limits on the size of mortgages eligible for FHA insurance or that receive proportionally less backing from the VA, thus reducing their participation in these programs.

Like lower-income borrowers, black and Hispanic borrowers tend to use FHA and VA mortgages relatively often. On average, borrowers in the latter group, compared with their white or Asian counterparts, have lower incomes, less wealth, weaker credit histories, and less-stable employment, and they purchase homes with lower values. In addition, black and Hispanic borrowers are more likely than equally qualified white and Asian borrowers to choose FHAbacked mortgages. ${ }^{10}$

A third nonprofit government institution, the Government National Mortgage Association (Ginnie Mae), is active in the secondary mortgage market; it was created by the Congress to provide liquidity solely for federal housing initiatives. In contrast to other secondary-market institutions, which buy mortgages and sell securities backed by mortgages, Ginnie Mae does not purchase mortgages. Instead, Ginnie Mae guarantees the timely payment of interest and principal for privately issued securities backed by mortgages insured by the FHA or the VA. In our analysis we do not identify Ginnie Mae as a bearer of credit risk; instead, we assume that the entire risk of FHA mortgages is borne by the FHA and that the risk of VA mortgages is borne mainly by the VA. In practice, however, Ginnie Mae bears a small amount of credit risk if, for example, a lender servicing a security backed by FHA and VA loans is unable to make timely payments.

\section{The Profit-Seeking Conventional Mortgage System}

The conventional mortgage system is made up of numerous institutions whose profit-seeking drives them to spread the credit risk of conventional mortgages (that is, mortgages that are not insured by the federal government). ${ }^{11}$ These institutions are a

10. Glenn B. Canner, Stuart A. Gabriel, and J. Michael Woolley, "Race, Default Risk and Mortgage Lending: A Study of the FHA and Conventional Loan Markets," Southern Economic Journal, vol. 58 (July 1991), pp. 249-62.

11. One group of nonprofit institutions, credit unions, is also part of the conventional mortgage system. Because they account for a very small portion of the mortgage market, credit unions are not discussed in the text; however, they are included in the tables for completeness. diverse group: Some are government-sponsored and others are privately sponsored; some have the capacity to hold mortgages in their portfolios whereas others only insure mortgages; and some are strongly encouraged by government to help meet the credit needs of lower-income homebuyers and neighborhoods whereas others are given no such direction. The three main types of institution in the conventional mortgage system are private mortgage insurers, government-sponsored enterprises, and portfolio lenders.

\section{Private Mortgage Insurers}

Private mortgage insurers are profit-seeking institutions that insure, but do not originate or purchase, conventional mortgages. They are not subject to federal laws that encourage the provision of credit to lower-income borrowers or in lower-income neighborhoods, such as the Community Reinvestment Act.

Private mortgage insurance reduces a lender's credit risk by insuring against losses associated with default up to a contractually established percentage of the claim amount. ${ }^{12}$ In deciding whether to insure a particular mortgage, a PMI company acts as a review underwriter, evaluating both the creditworthiness of the prospective borrower and the adequacy of the collateral offered as security on the loan. Like the FHA and the VA, PMI companies deny insurance to prospective borrowers who are judged to pose undue credit risk; lenders are free to extend credit to such borrowers, but they must do so without the protection of private mortgage insurance. (See appendix A for data on the disposition of applications for private mortgage insurance in 1995.)

Private mortgage insurers focus on mortgages that have high loan-to-value ratios - a type of mortgage often used by lower-income borrowers. However, they neither receive government support nor have a government mandate to serve lower-income borrowers. Hence, PMI companies serve lower-income borrowers to the extent that it is profitable to do so. To some extent, PMI companies compete directly with the FHA and the VA to insure mortgages that have high loan-to-value ratios.

12. The claim amount on a defaulted loan generally includes the outstanding balance on the loan, delinquent interest payments, expenses incurred during foreclosure, costs to maintain the property, and advances the lender made to pay taxes and hazard insurance on the property. For more information on private mortgage insurers, see Glenn B. Canner, Wayne Passmore, and Monisha Mittal, "Private Mortgage Insurance," Federal Reserve Bulletin, vol. 80 (October 1994), pp. 883-99. 
For homebuyers, private mortgage insurance can differ markedly from FHA or VA insurance. ${ }^{13}$ Private mortgage insurance is generally less expensive for borrowers who do not need the underwriting flexibility offered by the FHA or the VA, and it is more available for borrowers seeking larger mortgages. However, many homebuyers, particularly lowerincome and minority homebuyers, need the FHA's and VA's more liberal underwriting standards, lower down payments, and lower cash requirements at closing to qualify for a mortgage.

\section{Government-Sponsored Enterprises}

Government-sponsored enterprises (GSEs) are privately owned institutions that blend the characteristics of public and private institutions; they receive certain benefits from their government sponsorship and in exchange are expected to advance certain public policy goals. ${ }^{14}$ The GSEs most prominent in the mortgage market, Fannie Mae and Freddie Mac, are, together with Ginnie Mae, the major players in the secondary mortgage market. ${ }^{15}$ In contrast to

13. From a lender's perspective, the insurance provided by private mortgage insurers and that provided by the FHA and the VA differ in the level of protection against credit losses. Whereas PMI companies typically limit coverage to 20 percent to 35 percent of the claim amount on a defaulted loan, the FHA covers 100 percent of the unpaid balance of the mortgage as well as most costs associated with the foreclosure and sale of the property. The VA provides loan guarantees, with the guaranteed proportion tied to the size of the mortgage; the guaranteed proportion may not cover all the lender's losses under all circumstances, particularly when property values are falling. For marginally qualified borrowers, some lenders may prefer the added protection afforded by FHA or VA insurance and may encourage these borrowers to apply for such mortgages.

14. For general descriptions of two GSEs-Fannie Mae and Freddie Mac-including the benefits they derive from government sponsorship and their affirmative obligations to promote home ownership among lower-income households, see Congressional Budget Office, "Assessing the Public Costs and Benefits of Fannie Mae and Freddie Mac," May 1996; General Accounting Office, "Housing Enterprises: Potential Impacts of Severing Government Sponsorship," May 1996; U.S. Department of Housing and Urban Development, "Privatization of Fannie Mae and Freddie Mac: Desirability and Feasibility," July 1996; and U.S. Department of the Treasury, "Government Sponsorship of the Federal National Mortgage Association and the Federal Home Loan Mortgage Corporation," July 11, 1996.

15. For 1995, these three institutions accounted for 58 percent of all mortgage purchases reported under HMDA (see Special Tables, table 4.41, Federal Reserve Bulletin, vol. 82 (September 1996), pp. A74-A75). While these institutions dominate secondary market activity, others-including commercial banks, savings associations, insurance companies, and pension funds-are also active purchasers of mortgages. These other institutions buy the same types of loans purchased by Fannie Mae and Freddie Mac, but they also provide a market for lenders that originate nonconforming loans, such as jumbo loans (loans larger than the maximum single-family mortgage that may be purchased by Fannie Mae and Freddie Mac), mobile home loans, loans with lower credit quality, and certain types of adjustablerate mortgages.
Ginnie Mae, which focuses on government-backed mortgages, Fannie Mae and Freddie Mac purchase conventional mortgages almost exclusively, accepting all or part of the credit risk of the mortgages they purchase. Many of these mortgages are securitized, while others are held directly in their portfolios.

Because Fannie Mae and Freddie Mac are profitseeking, they may not be able to bear the same degree of credit risk as the FHA or the VA. At the same time, they do not have as much latitude as purely private entities: They have in their charters a congressionally mandated affirmative obligation to promote home ownership among lower-income households. They also have annual affordable housing goals, established by the Department of Housing and Urban Development (HUD), for the purchase of mortgages to lower-income households and in targeted communities.

Even while Fannie Mae and Freddie Mac are encouraged to promote lending to lower-income households, their charters may also create barriers to such lending by limiting the risk they may bear: The mortgages they purchase, unless they carry private mortgage insurance or some other form of credit enhancement (for example, recourse to the lender), must have loan-to-value ratios of 80 percent or less. Therefore, Fannie Mae and Freddie Mac generally bear the entire credit risk only for mortgages that have relatively large down payments-the type of mortgage that may be used less often by lowerincome households that have limited savings (some lower-income households, such as retirees, may have substantial financial assets).

\section{Portfolio Lenders}

Portfolio lenders are privately sponsored institutions that are capable of holding mortgages in their own portfolios; among these institutions are commercial banks, savings associations, and some mortgage banks. Portfolio lenders determine their own underwriting standards for the mortgages they hold, thereby controlling the credit risk of their portfolios.

The vast majority of portfolio lenders are depository institutions. However, a diverse group of nondepository portfolio lenders - mortgage bankers, pension funds, insurance companies, and others-also fund mortgages and bear mortgage credit risk. Depository institutions are subject to federal laws and regulations that require them to help meet the credit needs of lower-income households and neighborhoods, but nondepository portfolio lenders are not subject to such rules. 
Depository Institutions Subject to CRA. Depository institutions benefit from federal deposit insurance and from other services available exclusively to depository institutions. In exchange, they are subject to many regulations not imposed on other portfolio lenders. Among these regulations is the Community Reinvestment Act (CRA), which requires commercial banks and savings associations (but not credit unions) to help meet the credit needs of their communities. ${ }^{16}$

Opposing influences act on depository institutions to affect the extent of their lending to lower-income and minority borrowers and the extent to which they keep these mortgages in their portfolios. On one hand, CRA requirements may lead some depositories to hold mortgages underwritten with greater flexibility than those insured by private mortgage insurers or sold into the secondary market- the type of mortgages often sought by lower-income and minority homebuyers. Moreover, because they may find it difficult to originate and fund traditional thirty-year fixed-rate mortgages profitably, depositories may seek out market niches, collecting better information about a particular group of mortgage borrowers, or may develop products that meet special credit needs. ${ }^{17}$ Under these circumstances, they may hold relatively high proportions of nontraditional mortgages, including those extended to lower-income and minority borrowers.

On the other hand, because extending mortgages using more flexible underwriting standards may involve more risk-taking, depository institutions may be tempted to assume the risk of only the least risky mortgages and to pass that of higher-risk mortgages to other institutions, either by selling the loans or by obtaining insurance on them from a third party. ${ }^{18}$ They may find it difficult to sell such mortgages, however, because purchasers and insurers guard against accepting the risk of higher-risk mortgages by setting stricter underwriting standards than they would if they had full information about the mortgages' riskiness and by monitoring closely the

16. In our analysis we combined the lending activities of commercial banks and savings associations with those of their mortgage banking subsidiaries and affiliates. The CRA regulations allow banks and savings associations to include the lending activities of these institutions when CRA performance is evaluated.

17. See Joseph Blalock, "Successful Fixed-Rate Lending," Savings and Community Banker (February 1994), p. 38; and Wayne Passmore, "Can Retail Depositories Fund Mortgages Profitably?" Journal of Housing Research, vol. 3, no. 2 (1992), pp. 305-40.

18. For a discussion of this behavior, see Wayne Passmore and Roger Sparks, "Putting the Squeeze on a Market for Lemons: Government-Sponsored Mortgage Securitization," Journal of Real Estate Finance and Economics, vol. 13 (July 1996), pp. 27-43. adherence of mortgage originators to those standards. Risk-adjusted capital requirements also discourage depository institutions from holding some types of nonconforming loans: For mortgages having a loanto-value ratio of more than 80 percent and no private mortgage insurance, they must hold more capital to guard against losses.

Nondepository Portfolio Lenders. Independent mortgage bankers and private nondepository mortgage purchasers, such as life insurance companies and pension funds, are among the other profit-seeking portfolio lenders that hold credit risk associated with mortgages. These institutions often focus on particular portions of the mortgage market, such as jumbo loans, mobile home loans, some types of adjustablerate loans, and loans to borrowers who have poor credit histories or other credit characteristics that make their loans nontraditional.

Nondepository portfolio lenders are not subject to the CRA or to other laws intended to encourage lending to lower-income households and neighborhoods. However, like other participants in the mortgage market, they are subject to fair lending laws and to community pressures to be sensitive to the credit needs of lower-income and minority borrowers and neighborhoods. These institutions may also be subject to regulations and other influences that affect their propensity to hold particular types of mortgages in portfolio. For example, life insurance companies are subject to risk-adjusted capital requirements that impose higher capital requirements on mortgages held directly rather than in the form of a mortgagebacked security.

\section{THE MEASUREMENT OF PERFORMANCE IN LENDING TO LOWER-INCOME AND MINORITY HOMEBUYERS}

Several government reports, and extensive debates surrounding the recent rewriting of the CRA regulations, point to continued public interest in the performance of the major mortgage market participants in serving the mortgage credit needs of lower-income households. During the past year, four congressionally mandated government reports reviewed the role of Fannie Mae and Freddie Mac in mortgage markets and discussed their performance in serving the credit needs of lower-income homebuyers. ${ }^{19}$ Generally,

19. These reports, cited in footnote 14 , were required by the Federal Housing Enterprises Financial Safety and Soundness Act of 1992. 
these discussions supported our earlier finding that Fannie Mae and Freddie Mac finance a smaller portion of loans to lower-income homebuyers than do the FHA, the VA, or depository institutions. However, two of the reports emphasized that it is premature to judge these GSEs' performance in encouraging lending to lower-income households because their affordable housing goals set by HUD have been in place only a short period.

The findings of another recent government report, which compared the FHA's performance in financing loans to lower-income and minority households with that of other major institutions in the mortgage market, are also consistent with our previous research. It concluded that "FHA serves disproportionate fractions of lower-income households, blacks and Hispanics, first-time homebuyers, borrowers making low down payments, and households living in underserved neighborhoods when compared with private mortgages insurers, the government-sponsored enterprises, and conventional lenders." 20

Left unanswered is the larger question of whether the performance of one institution relative to another is the appropriate measure of how well the two institutions are meeting these needs. One institution or type of institution may be performing poorly compared with another, but it may be performing well given the other standards and expectations of the Congress, regulators, and shareholders. While the Congress has focused a variety of institutions toward meeting the needs of lower-income homebuyers-the FHA, depository institutions under CRA, and the GSEs with their affordable-housing goals-it has not specified how performance is to be measured; criteria for measuring performance have therefore been set by regulators.

Shareholders expect their firms to earn a competitive rate of return on their equity. The extent to which profit-seeking institutions subject to regulations encouraging lending to lower-income households should be expected to forgo profits in pursuit of such lending is unclear. To date, the Congress has allowed that these institutions are not expected to significantly diminish their profitability or to endanger their safety and soundness. ${ }^{21}$ Hence, one limitation of directly comparing performance across institutions is that

20. See HUD, “An Analysis of FHA's Single-Family Insurance Program," p. ES-1.

21. There is little evidence that profits have been significantly diminished by such lending. See Glenn B. Canner and Wayne Passmore, "The Relative Profitability of Commercial Banks Active in Lower-Income Neighborhoods and to Lower-Income Borrowers," in Proceedings of the 32nd Annual Conference on Bank Structure and Competition (Federal Reserve Bank of Chicago, 1996), pp. 531-55. such comparisons may not take into consideration other public and private goals. Recognizing this limitation is particularly important when nonprofit government organizations, such as the FHA and the VA, are compared with profit-seeking institutions.

Moreover, comparing performance on the basis of the bearing of credit risk, as we do, does not take into account efforts to encourage lending to lower-income households and neighborhoods. Almost all institutions in the mortgage market are making special efforts to extend home ownership to borrowers and communities that have traditionally received relatively small proportions of mortgage credit. For example, depository institutions, mortgage bankers, Fannie Mae and Freddie Mac, and the private mortgage insurers have worked together to introduce a host of new programs targeted at lower-income households; prominent among these are Fannie Mae's Community Home Buyers program and Freddie Mac's Affordable Gold program, both of which allow more flexible underwriting standards for the loans these institutions purchase. Recently, these institutions and others have jointly established the American Homeowner Education and Counseling Institute to improve both the education of individuals who counsel potential and current homebuyers and the effectiveness of that counseling. ${ }^{22}$

As important as these programs are-and despite concerns about comparing performance and the lack of perfect measurement criteria-the fact remains that the acceptance of credit risk is at the heart of mortgage lending. Without an institution willing to bear the credit risk of mortgage lending to lowerincome and minority households and neighborhoods, such mortgages cannot be made. Originators, funders, and purchasers of mortgages are numerous once an institution agrees to bear the credit risk of lending. The bearer of credit risk is therefore the crucial participant in the mortgage lending process.

\section{THE COMPOSITION OF MORTGAGE ACTIVITY IN 1995}

To identify which institutions bore the credit risk for mortgage lending to lower-income and minority borrowers and neighborhoods in 1995, we first looked at mortgages extended by size, by borrower and neighborhood characteristics, and by mortgage holder.

22. Press release, "American Homeowner Education and Counseling Institute to be Established; Will Lead Industry-wide Effort to Improve Homeowner Education and Counseling Efforts Nationwide," Fannie Mae, May 29, 1996. 


\section{Mortgage Borrowers and Loan Size}

We began by assigning each mortgage for the purchase of an owner-occupied home extended during the first ten months of 1995 to one of three loan-size categories: (1) FHA-eligible, (2) GSE-eligible only (GSEO-eligible), and (3) jumbo. The first category was based on size restrictions on FHA loans for the purchase of single-family homes. In 1995, the legislated limit in most areas of the country was $\$ 77,197$; it ranged up to $\$ 152,362$ for areas with high housing prices and even higher for Alaska and Hawaii. About 71 percent of all mortgages extended in 1995 for the purchase of owner-occupied homes were FHAeligible (table 1, memo item). Even higher proportions of loans to lower-income borrowers (98 percent) and black or Hispanic borrowers (84 percent) were FHA-eligible.
The GSEO-eligible category covered mortgages that exceeded the FHA's single-family mortgage size limits but not the limits on mortgages that Fannie Mae and Freddie Mac may purchase $(\$ 203,150$ in 1995, with higher limits for Alaska and Hawaii). About 23 percent of all mortgages extended in 1995 for the purchase of owner-occupied homes were GSEO-eligible. Fewer than 2 percent of loans to lower-income borrowers, and just over 13 percent of loans to black or Hispanic borrowers, were in this category.

The jumbo category was for mortgages exceeding $\$ 203,150$. About 7 percent of all mortgages extended in 1995 for the purchase of owner-occupied homes were in this category. Almost none of the loans to lower-income borrowers, and fewer than 3 percent of loans to black or Hispanic borrowers, were jumbo mortgages.

1. Mortgage loans extended in 1995, grouped by size and distributed by the characteristics of the borrowers and of the census tracts in which the properties are located

\begin{tabular}{|c|c|c|c|c|c|c|c|c|c|c|c|c|}
\hline \multirow[b]{2}{*}{ Characteristic } & \multicolumn{3}{|c|}{ FHA-eligible } & \multicolumn{3}{|c|}{ GSEO-eligible } & \multicolumn{3}{|c|}{ Jumbo } & \multicolumn{3}{|c|}{ All } \\
\hline & Number & Percent & $\begin{array}{l}\text { Мемо: } \\
\text { As a per- } \\
\text { centage } \\
\text { of charac- } \\
\text { teristic }\end{array}$ & Number & Percent & $\begin{array}{l}\text { Мемо: } \\
\text { As a per- } \\
\text { centage } \\
\text { of charac- } \\
\text { teristic }\end{array}$ & Number & Percent & $\begin{array}{l}\text { Мемо: } \\
\text { As a per- } \\
\text { centage } \\
\text { of charac- } \\
\text { teristic }\end{array}$ & Number & Percent & $\begin{array}{l}\text { Мемо: } \\
\text { As a per- } \\
\text { centage } \\
\text { of charac- } \\
\text { teristic }\end{array}$ \\
\hline \multicolumn{13}{|l|}{ BORROWER } \\
\hline Lower ........... & 563,846 & 38.0 & 98.1 & 10,257 & 2.2 & 1.8 & 605 & .4 & .1 & 574,708 & 27.4 & 100 \\
\hline Middle ................ & 535,320 & 36.1 & 84.9 & 91,192 & 19.2 & 14.5 & 3,769 & 1.7 & 6 & 630,281 & 30.0 & 100 \\
\hline Upper . . & 384,059 & 25.9 & 43.0 & 373,866 & 78.7 & 41.8 & 136,073 & 96.9 & 15.2 & 893,998 & 42.6 & 100 \\
\hline Total & $1,483,225$ & 100 & 70.7 & 475,315 & 100 & 22.6 & 140,447 & 100 & 6.7 & $2,098,987$ & 100 & 100 \\
\hline \multicolumn{13}{|l|}{ Racial or ethnic identity } \\
\hline or white $\ldots . . . . .$. & $1,154,635$ & 77.8 & 68.9 & 400,559 & 84.3 & 23.9 & 121,160 & 86.3 & 7.2 & $1,676,354$ & 79.9 & 100 \\
\hline Black or Hispanic ........ & 247,411 & 16.7 & 84.3 & 38,602 & 8.1 & 13.2 & 7,313 & 5.2 & 2.5 & 293,326 & 14.0 & 100 \\
\hline Other $^{2} \ldots \ldots \ldots \ldots$ & 81,179 & 5.5 & 62.8 & 36,154 & 7.6 & 28.0 & 11,974 & 8.5 & 9.3 & 129,307 & 6.2 & 100 \\
\hline Total & $1,483,225$ & 100 & 70.7 & 475,315 & 100 & 22.6 & 140,447 & 100 & 6.7 & $2,098,987$ & 100 & 100 \\
\hline \multicolumn{13}{|l|}{ Census Tract } \\
\hline Lower... & 229,214 & 15.5 & 91.3 & 18,248 & 3.8 & 7.3 & 3,652 & 2.6 & 1.5 & 251,114 & 12.0 & 100 \\
\hline Middle ... & 856,660 & 57.8 & 79.7 & 187,410 & 39.4 & 17.4 & 31,031 & 22.1 & 2.9 & $1,075,101$ & 51.2 & 100 \\
\hline Upper .... & 397,351 & 26.8 & 51.4 & 269,657 & 56.7 & 34.9 & 105,764 & 75.3 & 13.7 & 772,772 & 36.8 & 100 \\
\hline Total & $1,483,225$ & 100 & 70.7 & 475,315 & 100 & 22.6 & 140,447 & 100 & 6.7 & $2,098,987$ & 100 & 100 \\
\hline \multicolumn{13}{|l|}{$\begin{array}{l}\text { Minorities (as a } \\
\text { percentage of population) }\end{array}$} \\
\hline Less than $10 \ldots \ldots \ldots$. & 743,583 & 50.1 & 68.0 & 278,431 & 58.6 & 25.5 & 71,804 & 51.1 & 6.6 & $1,093,818$ & 52.1 & 100 \\
\hline $10-49 \ldots \ldots \ldots \ldots \ldots$ & 592,271 & 39.9 & 71.4 & 174,504 & 36.7 & 21.0 & 63,283 & 45.1 & 7.6 & 830,058 & 39.5 & 100 \\
\hline $50-100 \ldots$ & 147,371 & 9.9 & 84.2 & 22,380 & 4.7 & 12.8 & 5,360 & 3.8 & 3.1 & 175,111 & 8.3 & 100 \\
\hline Total & $1,483,225$ & 100 & 70.7 & 475,315 & 100 & 22.6 & 140,447 & 100 & 6.7 & $2,098,987$ & 100 & 100 \\
\hline Total & $1,483,225$ & $\ldots$ & 70.7 & 475,315 & $\ldots$ & 22.6 & 140,447 & $\cdots$ & 6.7 & $2,098,987$ & $\cdots$ & 100 \\
\hline
\end{tabular}

NoTE. Includes only owner-occupied home purchase mortgages originated in 1995 for which action on the application was taken before November 1, 1995 , and for which the property securing the mortgage was located in a metropolitan statistical area (MSA).

FHA-eligible: Loans that fell within the FHA mortgage size limits for single-family homes in 1995 . Some FHA mortgages are larger than the mortgage limits used for the FHA-eligible category because the FHA establishes higher mortgage limits for two-, three-, and four-family properties. GSEOeligible: Loans that exceeded the FHA single-family mortgage limits but not the maximum single-family loan size that could be purchased by Fannie Mae or Freddie Mac in 1995. Jumbo: Loans that exceeded the Fannie Mae and Freddie Mac limits.

1. Lower: Less than 80 percent of the median family income of the MSA in which the property related to the loan is located. Middle: 80 percent to 120 percent. Upper: 120 percent or more.

2. Includes American Indian or Alaskan native, other minorities, and joint (white and minority co-borrowers) as well as borrowers for whom racial or ethnic identity was not reported.

3. Lower: Median family income for census tract less than 80 percent of the median family income of the MSA in which the census tract is located. Middle: 80 percent to 120 percent. Upper: 120 percent or more.

. Not applicable.

Source. 1995 HMDA data. 


\section{Unadjusted Distribution of Mortgage Lending}

The allocation of credit risk across mortgage holders, insurers, and purchasers depends on underlying assumptions about risk-mitigation activities, business relationships, loan-to-value ratio distributions, default rates, and loss severity rates. Because views about the appropriate assumptions may differ, we provide information about the number and dollar amount of mortgages before adjusting the data to create our measure of credit risk.

Measuring the overall distribution of mortgage lending in 1995 in terms of the number of home purchase loans extended, before adjustments to account for private mortgage insurance coverage, indicates that commercial banks and savings associations held or purchased about 37 percent of the mortgages originated (total column in table 2). ${ }^{23}$

23. This number is the sum of the three rows labeled "Depository institutions subject to CRA" in table 2. Other numbers given in this paragraph similarly are sums across categories. The mortgages insured by the FHA are not included in any other categories because the FHA is assumed to bear all of the credit risk for the loans they insure. For this portion of the discussion, mortgages backed by the VA and by private mortgage insurers are assigned to the originator or purchaser that shares the credit risk with these institutions; later, we allocate the risk of these mortgages among the originators, purchasers, and insurers.

2. Mortgages extended in 1995 , grouped by size and distributed by mortgage system and type of holder Percent

\begin{tabular}{|c|c|c|c|c|c|c|c|c|}
\hline \multirow{2}{*}{$\begin{array}{l}\text { Mortgage system and } \\
\text { type of holder }\end{array}$} & \multicolumn{2}{|c|}{ FHA-eligible } & \multicolumn{2}{|c|}{ GSEO-eligible } & \multicolumn{2}{|c|}{ Jumbo } & \multicolumn{2}{|c|}{ Total } \\
\hline & By number & $\begin{array}{l}\text { By dollar } \\
\text { amount }\end{array}$ & By number & $\begin{array}{l}\text { By dollar } \\
\text { amount }\end{array}$ & By number & $\begin{array}{l}\text { By dollar } \\
\text { amount }\end{array}$ & By number & $\begin{array}{l}\text { By dollar } \\
\text { amount }\end{array}$ \\
\hline \multicolumn{9}{|l|}{$\begin{array}{c}\text { GOVERNMENT MoRTGAGE SySTEM: } \\
\text { LOANS WITH } \\
\text { GOVERNMENT INSURANCE }\end{array}$} \\
\hline FHA $\ldots \ldots \ldots \ldots \ldots \ldots \ldots \ldots \ldots$ & 24.3 & 26.0 & 3.4 & 3.0 & .2 & .2 & 18.0 & 13.7 \\
\hline $\begin{array}{l}\mathrm{VA}^{1} \ldots \ldots \ldots \ldots \ldots \ldots \ldots \ldots \ldots \ldots \ldots \\
\quad \text { Depository institutions subject to }\end{array}$ & 6.8 & 7.6 & 8.9 & 8.6 & $*$ & $*$ & 6.8 & 6.4 \\
\hline $\mathrm{CRA}^{2} \ldots \ldots \ldots \ldots \ldots$ & 3.9 & 4.2 & 4.7 & 4.4 & * & $*$ & 3.8 & 3.4 \\
\hline Independent mortgage companies ${ }^{3}$ & 2.8 & 3.3 & 4.1 & 4.1 & $*$ & $*$ & 2.9 & 2.9 \\
\hline Credit unions $\ldots \ldots \ldots \ldots \ldots \ldots \ldots$ & .1 & .1 & .1 & .1 & $*$ & * & .1 & .1 \\
\hline \multicolumn{9}{|l|}{ 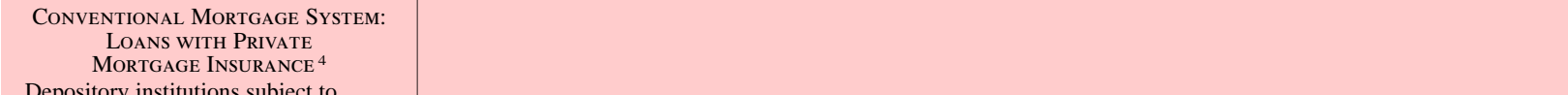 } \\
\hline $\begin{array}{l}\text { Depository institutions subject to } \\
\text { CRA }^{2} \ldots \ldots \ldots \ldots \ldots \ldots \ldots \ldots \ldots \ldots\end{array}$ & 5.8 & 6.3 & 8.0 & 7.7 & 9.7 & 8.1 & 6.6 & 7.1 \\
\hline Fannie Mae and Freddie Mac ......... & 9.2 & 10.3 & 13.1 & 12.8 & .6 & .4 & 9.5 & 9.1 \\
\hline Independent mortgage companies ${ }^{3}$ & .5 & .6 & .8 & .7 & .6 & .5 & .6 & .6 \\
\hline Other $^{5} \ldots \ldots \ldots \ldots \ldots \ldots \ldots \ldots \ldots \ldots \ldots \ldots \ldots \ldots$ & 2.1 & 2.4 & 3.3 & 3.2 & 3.5 & 2.8 & 2.4 & 2.7 \\
\hline Credit unions $\ldots \ldots \ldots \ldots \ldots \ldots \ldots$ & .2 & .2 & .2 & .2 & .1 & $*$ & .2 & .2 \\
\hline Total $\ldots \ldots \ldots \ldots \ldots \ldots \ldots \ldots \ldots \ldots$ & 17.8 & 19.8 & 25.4 & 24.6 & 14.5 & 11.8 & 19.3 & 19.7 \\
\hline \multicolumn{9}{|l|}{$\begin{array}{c}\text { CONVENTIONAL MoRTGAGE SySTEM: } \\
\text { LOANS WITHOUT PRIVATE } \\
\text { MORTGAGE INSURANCE }{ }^{4}\end{array}$} \\
\hline $\begin{array}{l}\text { Government-sponsored enterprises } \\
\text { (Fannie Mae or Freddie Mac) } \ldots\end{array}$ & 16.4 & 18.0 & 27.3 & 28.2 & 2.3 & 2.0 & 17.9 & 18.1 \\
\hline \multicolumn{9}{|l|}{$\begin{array}{l}\text { Portfolio lenders } \\
\text { Depository institutions subject to }\end{array}$} \\
\hline $\mathrm{CRA}^{2} \ldots \ldots \ldots \ldots \ldots \ldots$ & 23.6 & 19.5 & 24.4 & 24.7 & 59.2 & 62.5 & 26.2 & 29.5 \\
\hline Independent mortgage companies ${ }^{3}$ & 2.3 & 2.0 & 2.2 & 2.2 & 6.2 & 6.0 & 2.6 & 2.9 \\
\hline Other ${ }^{5} \ldots \ldots \ldots \ldots \ldots \ldots \ldots \ldots$ & 7.9 & 6.5 & 7.7 & 7.9 & 17.1 & 16.7 & 8.4 & 8.9 \\
\hline Credit unions $\ldots \ldots \ldots \ldots \ldots \ldots$ & 1.0 & .8 & .8 & .8 & .6 & .6 & .9 & .7 \\
\hline Total & 100 & 100 & 100 & 100 & 100 & 100 & 100 & 100 \\
\hline \multirow{2}{*}{$\begin{array}{l}\text { Memo: } \\
\text { Number of loans (and percentage } \\
\quad \text { distribution) } \ldots \ldots \ldots \ldots \ldots \ldots \ldots \ldots \\
\text { Amount of loans, in millions of dollars } \\
\quad \text { (and percentage distribution) } \ldots \ldots\end{array}$} & $\begin{array}{l}1,483,225 \\
(70.7)\end{array}$ & & $\begin{array}{c}475,315 \\
(22.6)\end{array}$ & & $\begin{array}{l}140,447 \\
(6.7)\end{array}$ & & $\begin{array}{l}2,098,987 \\
(100.0)\end{array}$ & \\
\hline & & $\begin{array}{c}110,370 \\
(49.1)\end{array}$ & & $\begin{array}{r}70,423 \\
(31.3)\end{array}$ & ... & $\begin{array}{r}44,035 \\
(19.6)\end{array}$ & $\cdots$ & $\begin{array}{r}224,827 \\
(100.0)\end{array}$ \\
\hline \multicolumn{9}{|c|}{$\begin{array}{l}\text { NoTE. Distributions are based on unadjusted dollars (see text). Also see } \\
\text { general note to table } 1 \text {. } \\
\text { 1. Data reported by originator of mortgage. } \\
\text { 2. Includes mortgages originated and held in portfolio by commercial banks } \\
\text { and savings associations and their mortgage company affiliates and mortgages } \\
\text { sold to commercial banks or savings associations. }\end{array}$} \\
\hline
\end{tabular}

3 . Includes mortgages originated and held in portfolio by independent mortgage companies and mortgages sold to affiliates by independent mortgage companies. 
Fannie Mae and Freddie Mac purchased about 27 percent, and the FHA backed 18 percent. The remaining 18 percent were held by privately sponsored nondepository institutions, such as independent mortgage companies or their affiliates, or by credit unions.

For the smallest loan-size category, market shares differed somewhat. The FHA backed about 24 percent of FHA-eligible mortgages measured by number of loans. Commercial banks and savings associations held or purchased 33 percent (again summing across loans backed and not backed by private mortgage insurance or the VA), somewhat lower than that group's share of mortgages of all sizes, while the share purchased by Fannie Mae and Freddie Mac was only slightly lower.

When the overall distribution of mortgage lending is measured in terms of dollar amount rather than

\section{Matching HMDA and PMI Records}

To determine which mortgages were covered by private mortgage insurance, we compared individual home mortgage records for 1995 submitted under HMDA with individual records for that year submitted by private mortgage insurers. Mortgages were identified as privately insured if records in the two files "matched" on the following characteristics: purpose of loan, location of the property securing the loan (same state, metropolitan statistical area, county, and census tract), borrower race or ethnic status, loan size, and borrower income. To be considered matches, the records had to list the same loan purpose and property location; race or ethnic status had to be the same unless that information was missing from the PMI record, in which case the records were considered to match if all other criteria were satisfied.

To check for matches on loan size and borrower income, we did two iterations. In the first, we considered the records to match if loan size or borrower income, or both, differed by no more than $\$ 5,000$. Of these matches, more than 75 percent did not differ on loan size and more than 50 percent did not differ on borrower income. In the second iteration, which considered only PMI and HMDA records that had not been matched in the first iteration, loan size had to be within $\$ 1,000$ but income could differ by as much as $\$ 10,000 .{ }^{1}$ This second iteration resulted in an additional 19,400 matches, bringing to 404,073 the total number of conventional mortgages we identified as privately insured ( 25.6 percent of the $1,579,681$ conventional mortgages for home purchase in our database).

1. In an earlier analysis we considered records to match only if they were nearly identical on all characteristics. Here we allowed loan size and borrower income to differ somewhat more because it seemed that changes in borrower circumstances and measurement error might cause a borrower's HMDA and PMI records to differ on these criteria. number of loans, the relative proportions held by institutions change in a way that reflects their specialization by loan size. The proportion of mortgages originated and held by or purchased by commercial banks and savings associations rises to 40 percent, reflecting the relatively large presence of these institutions in the jumbo mortgage market. Similarly, the FHA's proportion falls to 14 percent, reflecting the limits on the size of mortgages it may insure.

\section{Estimation of PMI Coverage}

A complete picture of how credit risk is distributed requires knowledge of which conventional mortgages were backed by private mortgage insurance. Coverage by FHA or VA insurance is reported in the HMDA data, but information on coverage of conventional mortgages by private mortgage insurance is not readily available. Therefore, we estimated PMI coverage by matching the individual mortgage records reported under HMDA with individual records on loans insured by private mortgage insurers (see box "Matching HMDA and PMI Records"). The matching techniques used here differ from those used in our study of mortgage lending in 1994, and comparisons across years are not appropriate. ${ }^{24}$

From our matching process, we estimated that roughly 20 percent of the conventional mortgages that were originated and retained by or purchased by depository institutions or their subsidiaries (measured by number of loans) were backed by private mortgage insurance (derived from table 2). That most of these conventional mortgages were not backed by private mortgage insurance implies that depository institutions bear the entire credit risk for most of the conventional mortgages they hold.

24. In our previous study we used statistical matching with replacement to match PMI and HMDA records (when a PMI record matched a HMDA record, the PMI record was retained for possible additional matches); here we use statistical matching without replacement (the PMI record was dropped once it matched a HMDA record). Earlier we allocated all of the credit risk of a PMI-insured mortgage to the insurer and therefore did not need to know which institution originated or purchased the mortgage; here we allocate the credit risk for a given mortgage among institutions and therefore had to know the identity of the originator or purchaser-information that is available only from the HMDA record that actually matches the PMI record.

In the matching process for the current study we made several additions to the process used earlier (see box). We added matches on dates of loan approval and PMI approval to better identify matches, randomized the order of HMDA records before matching to remove any potential for bias resulting from the ordering of HMDA data in the Federal Financial Institution Examination Council databases, and changed the matching criteria to allow greater differences in loan size and income. The net result of these changes was more matches, which increased the calculated market share for private mortgage insurers. 
By the same process, we estimated that 35 percent of the mortgages purchased by Fannie Mae and Freddie Mac were backed by private mortgage insurance. In contrast to our estimates, industry sources indicated that nearly half of the home purchase mortgages bought in 1995 by Fannie Mae and Freddie Mac were insured by private mortgage insurance. The difference between that figure and our estimate may be a consequence of the large number of PMI records (31 percent) and HMDA records (23 percent) for which detailed geographic information was not reported. (As noted in the box describing the matching process, our procedure required that "matching" records match on the location of the property being financed.) The lack of geographic information on PMI records is unlikely to be related to the type of mortgage holder or purchaser, however, and therefore the extent of PMI coverage is probably understated for other institutions as well. As described in appen$\operatorname{dix} B$, we accounted for these differences in our estimates of risk-bearing.

\section{THE HOLDERS OF CREDIT RISK ON MORTGAGES EXTENDED IN 1995}

To estimate credit risk, we converted data on the dollar amount of mortgages extended or insured ("unadjusted dollars") to risk dollars-the long-term dollar losses that could be expected on the basis of historical experience. This conversion process involved using loan-to-value ratio (LTV) distributions for each type of institution; estimating the extent of PMI use across institutions; applying historical default and loss severity rates by loan-to-value ratio for each type of institution; and reallocating these risk dollars across institutions to account for risksharing arrangements between insurers and other institutions. (Details of the conversion process are given in appendix B.) Because of the public-interest focus on lower-income and minority borrowers and on lower-income and predominantly minority neighborhoods, we present results only for FHA-eligible mortgages. ${ }^{25}$

We measured the amount of credit risk borne by each type of institution in two ways: the share of the institution's portfolio extended to a particular group

25. Many households that purchase homes with mortgages larger than the FHA-eligible category limit are not lower income or are lower income but have substantial wealth. Affordable housing initiatives are not intended for these households, although some of them may benefit from these efforts. See Glenn B. Canner and Wayne Passmore, "Implementing CRA: What is the Target?" in Proceedings of the 31st Annual Conference on Bank Structure and Competition (Federal Reserve Bank of Chicago, 1995), pp. 171-91. of borrowers (portfolio share) and the share of the total dollars extended by an institution to a particular group relative to the total dollars extended by all lenders to that group (market share). The portfolio and market shares are calculated using both unadjusted dollars and risk dollars. Dollar amounts unadjusted for credit risk are reported to provide a point of reference; however, risk dollars are a better measure of risk-bearing and are at the heart of our analysis.

\section{Portfolio Shares}

Of the major participants in the home mortgage market, the FHA had the highest proportion of its risk dollars extended to lower-income and black or Hispanic borrowers and in lower-income and predominantly minority neighborhoods (table 3 ). This finding is not surprising because the FHA is governmentbacked and government-subsidized and thus is able to use more-flexible underwriting standards than many of the other major participants in the mortgage market. The other government agency that directly backs mortgages, the VA, also had a relatively large proportion of its risk dollars in lending to lowerincome and black or Hispanic borrowers. However, the VA was not among the higher-ranking institutions for lending in lower-income and predominantly minority neighborhoods.

Among the profit-oriented institutions in the conventional mortgage system, portfolio lenders had relatively large proportions of their risk dollars in lending to lower-income borrowers and in lowerincome neighborhoods. This finding may partly reflect the ability of these institutions to profitably underwrite and hold the credit risk of nonconforming mortgages. It may also partly be a function of the rapid expansion of the secondary market for nonconforming mortgages, which has provided opportunities for purchasers such as pension funds and life insurance companies to become involved in nontraditional mortgage lending, such as purchasing loans to borrowers with weak credit histories or unusually high debt-payment-to-income ratios.

The portfolio shares of depository institutions subject to CRA requirements did not differ substantially from those of other portfolio lenders, possibly because both types of institutions are actively involved in nonconforming mortgage markets. The relatively high portfolio shares of conventional mortgages held by nondepository institutions may reflect that group's traditional orientation toward nonconforming mortgages, such as mortgages for mobile 
homes, as well as the extensive use of FHA programs by some nondepositories. Both pursuits may provide opportunities for greater involvement with lowerincome and minority borrowers. Similarly, CRArelated programs often generate nonconforming mortgages, perhaps accounting for the high portfolio shares of depository institutions.

The shares of the other major participants in the conventional mortgage market were generally similar to or somewhat smaller than those held by portfolio lenders. There were no striking differences among these institutions; the portfolio shares of Fannie Mae and Freddie Mac and those of private mortgage insurers were similar across all borrower and neighborhood categories.

\section{Market Shares}

An institution's underwriting standards and business strategy, along with its charter restrictions and regulatory environment, influence the institution's presence in a particular market. An institution that aggressively encourages mortgage applications from lowerincome and minority households may have a larger market share but a smaller portfolio share than one that makes only a few such mortgages.

The FHA dominated all other lenders in the aggregate amount of risk dollars extended to lower-income and black or Hispanic borrowers and for properties in lower-income and minority neighborhoods (table 4). About two-thirds of the risk dollars extended to these borrowers and neighborhoods were extended by the FHA. This finding reflects the large (unadjusted) dollar amount of mortgages extended to lowerincome and black or Hispanic borrowers, and in lower-income neighborhoods and minority neighborhoods, that were insured by the FHA. In addition, the FHA insured a relatively large proportion of mortgages having very high loan-to-value ratiosmortgages that tend to have relatively high default and loss severity rates. Moreover, the mortgage default and loss severity rates for the FHA's singlefamily mortgage portfolio are higher than those experienced by other mortgage lenders or insurers (table B.1).

None of the other institutions had a large market share relative to the FHA's share. The VA, the second largest holder of risk dollars, held only about onesixth as many risk dollars as the FHA. As with the FHA, the VA's portfolio included a high proportion of loans with high loan-to-value ratios, and these loans had higher default rates than conventional mortgages with similar LTVs, resulting in a relatively large market share.

The institutions in the conventional mortgage system all had market shares of 10 percent or less within any given borrower or neighborhood group. None of

3. Share of institutions' portfolios of FHA-eligible mortgages extended in 1995 to lower-income or black or Hispanic borrowers or in lower-income or predominantly minority census tracts, by mortgage system and type of holder Percent

\begin{tabular}{|c|c|c|c|c|c|c|c|c|}
\hline \multirow{3}{*}{$\begin{array}{l}\text { Mortgage system and } \\
\text { type of holder }\end{array}$} & \multicolumn{4}{|c|}{ Borrower characteristic } & \multicolumn{4}{|c|}{ Census tract characteristic } \\
\hline & \multicolumn{2}{|c|}{ Lower income } & \multicolumn{2}{|c|}{ Black or Hispanic } & \multicolumn{2}{|c|}{ Lower income } & \multicolumn{2}{|c|}{ Predominantly minority } \\
\hline & Unadjusted & Adjusted & Unadjusted & Adjusted & Unadjusted & Adjusted & Unadjusted & Adjusted \\
\hline Government Mortgage System & & & & & & & & \\
\hline FHA $\ldots \ldots \ldots \ldots \ldots \ldots \ldots \ldots \ldots \ldots \ldots$ & 37 & 38 & 27 & 24 & 16 & 15 & 13 & 13 \\
\hline VA $\ldots \ldots \ldots \ldots \ldots \ldots \ldots \ldots \ldots \ldots \ldots \ldots$ & 33 & 34 & 20 & 18 & 13 & 11 & 8 & 8 \\
\hline Conventional Mortgage System & & & & & & & & \\
\hline Private mortgage insurers ${ }^{1} \ldots \ldots \ldots \ldots$ & 25 & 26 & 15 & 13 & 12 & 10 & 9 & 9 \\
\hline $\begin{array}{l}\text { Government-sponsored enterprises } \\
\text { (Fannie Mae or Freddie Mac) }\end{array}$ & 24 & 26 & 9 & 14 & 9 & 10 & 8 & 9 \\
\hline \multicolumn{9}{|l|}{ Portfolio lenders } \\
\hline $\begin{array}{l}\text { Depository institutions subject to } \\
\text { CRA }^{2} \ldots \ldots \ldots \ldots\end{array}$ & 32 & 33 & 11 & 15 & 13 & 14 & 8 & 8 \\
\hline Independent mortgage companies ${ }^{3}$ & 28 & 32 & 17 & 19 & 14 & 13 & 13 & 10 \\
\hline Other $^{4} \ldots \ldots \ldots \ldots \ldots \ldots \ldots \ldots$ & 31 & 31 & 12 & 16 & 13 & 13 & 9 & 9 \\
\hline Credit unions $\ldots \ldots \ldots \ldots \ldots \ldots \ldots \ldots$ & 22 & 24 & 7 & 9 & 10 & 11 & 5 & 5 \\
\hline All holders & 30 & 35 & 16 & 20 & 13 & 14 & 10 & 11 \\
\hline $\begin{array}{l}\text { Note. Unadjusted shares are based on do } \\
\text { adjusted shares are based on risk dollars. } \\
\text { 1. Mortgages backed by private mortgag } \\
\text { 2. Includes mortgages originated and he } \\
\text { and savings associations and their mortgag } \\
\text { sold to commercial banks and savings assoc }\end{array}$ & $\begin{array}{l}\text { lar amounts of } \\
\text { insurers. } \\
\text { in portfolio b } \\
\text { company affi } \\
\text { ations. }\end{array}$ & $\begin{array}{l}\text { commercia } \\
\text { tes and mo }\end{array}$ & $\begin{array}{l}\text { ded; } \\
\text { anks } \\
\text { ages }\end{array}$ & $\begin{array}{l}\text { Includes mo } \\
\text { companies } \\
\text { panies. } \\
\text { Includes mo } \\
\text { private-sect } \\
\text { URCE. Deriv }\end{array}$ & $\begin{array}{l}\text { gages originat } \\
\text { id mortgages } \\
\text { gages sold to } \\
\text { purchasers. } \\
\text { d from } 1995 \mathrm{H}\end{array}$ & $\begin{array}{l}\text { and held in } \\
\text { old to affili } \\
\text { IDe insurance } \\
\text { IDA and PM }\end{array}$ & $\begin{array}{l}\text { ortfolio by ind } \\
\text { es by indeper } \\
\text { ompanies, pen } \\
\text { data. }\end{array}$ & $\begin{array}{l}\text { endent mort- } \\
\text { ent mortgage } \\
\text { on funds, and }\end{array}$ \\
\hline
\end{tabular}


4. Share of market for FHA-eligible mortgages extended in 1995 to lower-income or black or Hispanic borrowers or in lower-income or predominantly minority census tracts, by mortgage system and type of holder

Percent

\begin{tabular}{|c|c|c|c|c|c|c|c|c|c|c|}
\hline \multirow{3}{*}{$\begin{array}{l}\text { Mortgage system and } \\
\text { type of holder }\end{array}$} & \multicolumn{4}{|c|}{ Borrower characteristic } & \multicolumn{4}{|c|}{ Census tract characteristic } & \multirow{2}{*}{\multicolumn{2}{|c|}{ Total }} \\
\hline & \multicolumn{2}{|c|}{ Lower income } & \multicolumn{2}{|c|}{ Black or Hispanic } & \multicolumn{2}{|c|}{ Lower income } & \multicolumn{2}{|c|}{ Predominantly minority } & & \\
\hline & Unadjusted & Adjusted & Unadjusted & Adjusted & Unadjusted & Adjusted & Unadjusted & Adjusted & Unadjusted & Adjusted \\
\hline Government Mortgage System & & & & & & & & & & \\
\hline FHA $\ldots \ldots \ldots \ldots \ldots \ldots \ldots \ldots \ldots \ldots \ldots \ldots \ldots \ldots$ & 32 & 63 & 42 & 67 & 33 & 63 & 35 & 67 & 26 & 57 \\
\hline VA $\ldots \ldots \ldots \ldots \ldots \ldots \ldots \ldots \ldots \ldots \ldots \ldots \ldots \ldots \ldots \ldots$ & 8 & 12 & 9 & 11 & 7 & 10 & 7 & 9 & 8 & 12 \\
\hline Conventional Mortgage System & & & & & & & & & & \\
\hline Private mortgage insurers ${ }^{1} \ldots \ldots \ldots \ldots$ & 17 & 7 & 18 & 6 & 18 & 7 & 18 & 8 & 20 & 10 \\
\hline $\begin{array}{l}\text { Government-sponsored enterprises } \\
\text { (Fannie Mae or Freddie Mac) . }\end{array}$ & 14 & 4 & 10 & 4 & 13 & 4 & 14 & 5 & 18 & 6 \\
\hline $\begin{array}{l}\text { Portfolio lenders } \\
\text { Depository institutions subject to } \\
\quad \text { CRA }^{2} \ldots \ldots \ldots \ldots \ldots \ldots \ldots \\
\text { Independent mortgage companies } \\
\text { Other }{ }^{4} \ldots \ldots \ldots \ldots \ldots \ldots \ldots \ldots \ldots \\
\text { Credit unions } \ldots \ldots \ldots \ldots \ldots \ldots \ldots \ldots \ldots \ldots \ldots \ldots \ldots \ldots \ldots\end{array}$ & $\begin{array}{r}20 \\
2 \\
7 \\
1\end{array}$ & $\begin{array}{l}9 \\
2 \\
2 \\
*\end{array}$ & $\begin{array}{r}13 \\
2 \\
5 \\
*\end{array}$ & $\begin{array}{l}7 \\
2 \\
2 \\
*\end{array}$ & $\begin{array}{r}20 \\
2 \\
6 \\
1\end{array}$ & $\begin{array}{r}10 \\
2 \\
3 \\
*\end{array}$ & $\begin{array}{r}17 \\
3 \\
6 \\
*\end{array}$ & $\begin{array}{l}7 \\
2 \\
2 \\
*\end{array}$ & $\begin{array}{r}19 \\
2 \\
6 \\
1\end{array}$ & $\begin{array}{r}10 \\
2 \\
3 \\
*\end{array}$ \\
\hline All holders & 100 & 100 & 100 & 100 & 100 & 100 & 100 & 100 & 100 & 100 \\
\hline $\begin{array}{l}\text { NOTE. Unadjusted shares are based on } \\
\text { adjusted shares are based on risk dollars. } \\
\text { 1. Mortgages backed by private mortg } \\
\text { 2. Includes mortgages originated and } \\
\text { and savings associations and their mortg } \\
\text { sold to commercial banks and savings ass }\end{array}$ & $\begin{array}{l}\text { lollar amount } \\
\text { ge insurers. } \\
\text { eld in portfol } \\
\text { ge company } \\
\text { ciations. }\end{array}$ & $\begin{array}{l}\text { lio by comn } \\
\text { affiliates ar }\end{array}$ & $\begin{array}{l}\text { nercial banks } \\
\text { d mortgages }\end{array}$ & $\begin{array}{r}3 . \\
\text { gage } \\
\text { comp } \\
4 . \\
\text { other } \\
* \mathrm{~L} \\
\text { So }\end{array}$ & $\begin{array}{l}\text { Includes mor } \\
\text { companies a } \\
\text { anies. } \\
\text { Includes mor } \\
\text { private-sector } \\
\text { ess than } 0.5 p \\
\text { URCE. Derive }\end{array}$ & $\begin{array}{l}\text { rtgages orig } \\
\text { and mortga } \\
\text { rtgages sold } \\
\text { r purchaser } \\
\text { percent. } \\
\text { ed from } 199\end{array}$ & $\begin{array}{l}\text { inated and hel } \\
\text { ges sold to } \\
\text { to life insure } \\
\text { s. }\end{array}$ & $\begin{array}{l}\text { eld in portfol } \\
\text { affiliates by } \\
\text { rance compa } \\
\text { d PMI data. }\end{array}$ & $\begin{array}{l}\text { lio by indepe } \\
\text { independen } \\
\text { nies, pension }\end{array}$ & $\begin{array}{l}\text { ndent mort- } \\
\text { t mortgage } \\
\text { funds, and }\end{array}$ \\
\hline
\end{tabular}

these institutions seems to play a dominant role in the bearing of credit risk within this system. To some extent, profit-seeking drives institutions within this system to diversify risk across institutions: Institutions specialize in a part of the mortgage process or within certain market niches, and they often seek to share the risks they incur outside their specialization or niche. Regulatory or legislative constraints, such as the charter requirements restricting the bearing of credit risk of high-LTV mortgages by Fannie Mae and Freddie Mac and risk-adjusted capital requirements for depository institutions, also play a role.

Our calculations of market shares are subject to some uncertainty. We tried many different permutations of the underlying determinants of mortgage credit risk (loan-to-value distributions, default rates, loss severity rates, and risk-sharing arrangements) and found our results to be robust to reasonable changes in these determinants. For example, we calculated market and portfolio shares using alternative LTV distributions for portfolio lenders (appendix B). The primary effect was to alter the market share of depository institutions subject to CRA, reducing or raising the group's market share 2 to 3 percentage points. The gain or loss in market share was almost all accounted for by an offsetting change in the FHA's market share. The market shares of other institutions were mostly unaffected by this change.

\section{CONCLUSION}

We have revisited the question of who bears the credit risk of home purchase lending to lower-income and black or Hispanic borrowers and in lower-income and minority neighborhoods. In an earlier analysis we measured credit risk rather crudely and found that the FHA was a major bearer of credit risk for mortgage lending to these groups. Here we refine our measure of credit risk, making significant improvements in the way risk is allocated across institutions. To a much greater extent than before, we find that the FHA is the primary bearer of credit risk for home purchase loans to lower-income and black or Hispanic borrowers and in lower-income and minority neighborhoods.

The FHA dominates all other institutions in market share, holding about two-thirds of the total credit risk borne by all institutions for FHA-eligible mortgages extended in 1995 to lower-income and black or Hispanic borrowers and in lower-income and minority neighborhoods. The other major nonprofit government mortgage insurer, the VA, accounted for roughly one-tenth of the market. The FHA also had the greatest proportion of its credit risk portfolio in mortgages to lower-income and minority borrowers and neighborhoods.

In contrast, the conventional mortgage system bore only about one-fourth of the credit risk associated 
with FHA-eligible mortgages extended in 1995 to lower-income and black or Hispanic borrowers and in lower-income and minority neighborhoods. All of the institutions in this system had small market shares relative to the FHA's, and no single institution or set of institutions seems to have dominated the others. However, some of the participants in the conventional mortgage system, particularly portfolio lenders such as commercial banks, savings associations, and mortgage banks, had larger proportions of their credit risk portfolios in mortgages to lower-income borrowers and neighborhoods than did the other institutions in this system.

\section{APPENDIX A:}

\section{PRIVATE MORTGAGE INSURANCE IN 1995}

In 1993, the Mortgage Insurance Companies of America (MICA) asked the Federal Financial Institutions Examination Council (FFIEC) to process data from private mortgage insurance companies on applications for mortgage insurance and to produce public disclosure reports based on the data. ${ }^{26}$ The MICA request was a response to public and congressional interest in the activities of PMI companies as they relate to issues of fair lending, affordable housing, and community development.

PMI companies record data on each application for private mortgage insurance they act on during a given period. The data include the action taken on the application (approved, denied, withdrawn, or file closed because information was incomplete); the purpose of the mortgage for which insurance was sought (home purchase or refinance); the race or ethnic group, sex, and annual income of the applicant(s); the amount of the mortgage; and the geographic location of the property securing the mortgage.

The FFIEC summarizes the information in disclosure statements similar to those created for financial institutions covered by the Home Mortgage Disclosure Act (HMDA). Disclosure statements for each PMI company are publicly available at the company's corporate headquarters and at a central depository in each metropolitan statistical area (MSA) in which HMDA data are held. The central depository also holds aggregate data for all the PMI companies active in that MSA. In addition, the PMI data are

26. Founded in 1973, MICA is the trade association for the PMI industry. The costs to the FFIEC for processing the data, preparing disclosure statements and other reports, and disseminating the data are covered by the PMI companies through MICA. available from the Federal Reserve Board through its HMDA Assistance Line (202-452-2016).

This appendix summarizes the PMI data for calendar year $1995 .{ }^{27}$ Beginning with the release of the 1996 PMI data, summary tables of the types presented in this appendix will appear each year in the Financial and Business Statistics section of the September issue of the Federal Reserve Bulletin. The September Bulletin currently contains, in the same section, summary tables for the HMDA data for the preceding calendar year.

\section{Summary of the 1995 Data}

For 1995, the eight PMI companies that are actively writing home mortgage insurance submitted data to the FFIEC through MICA. In total, these companies acted on 1,236,237 applications for insurance: $1,108,512$ to insure home purchase mortgages on single-family properties and 127,725 to insure mortgages for refinancing existing mortgages (table A.1).

The total number of policies written in 1995 (that is, the total number of loans privately insured) was down about 15 percent from 1994, primarily because of a sharp decline in requests for PMI coverage for refinancings. The decline in applications to insure refinancings reflects a general decline in refinancings: From 1994 to 1995 the number of applications for conventional home refinancings reported in the HMDA data fell 35 percent whereas the number of applications for conventional home purchase loans declined only about 2 percent (data not shown in tables).

The two largest PMI companies, Mortgage Guaranty Insurance Corporation and GE Capital Mortgage Insurance Corporation, in 1995 accounted for about half of all applications for private mortgage insurance and half of all policies written, a drop from 1994, when the two companies accounted for 55 percent of all policies written (table A.2, 1994 data not shown). The decline in share is due entirely to a decline in activity by GE Capital. Two smaller companies, Amerin Guaranty and Commonwealth Mortgage Assurance, saw fairly sizable increases in their shares of the overall market.

The large share of PMI activity accounted for by Mortgage Guaranty and GE Capital extended across

27. For analyses of the 1993 and 1994 data, see, respectively, Canner, Passmore, and Mittal, "Private Mortgage Insurance," and Canner and Passmore, "Credit Risk and the Provision of Mortgages to Lower-Income and Minority Homebuyers." 
A.1. PMI applications received and policies written, grouped by purpose of loan and distributed by insurance company, 1995 Percent

\begin{tabular}{|c|c|c|c|c|c|c|}
\hline \multirow{2}{*}{ Company } & \multicolumn{2}{|c|}{ Home purchase } & \multicolumn{2}{|c|}{ Home refinance } & \multicolumn{2}{|c|}{ Total } \\
\hline & Applications & $\begin{array}{l}\text { Policies } \\
\text { written }\end{array}$ & Applications & $\begin{array}{l}\text { Policies } \\
\text { written }\end{array}$ & Applications & $\begin{array}{l}\text { Policies } \\
\text { written }\end{array}$ \\
\hline Amerin Guaranty $\ldots \ldots \ldots \ldots \ldots \ldots$ & 3.8 & 4.8 & 4.5 & 6.1 & 3.9 & 4.9 \\
\hline Commonwealth Mortgage Assurance & 10.1 & 9.6 & 12.2 & 11.2 & 10.3 & 9.8 \\
\hline GE Capital Mortgage Insurance ...... & 23.2 & 23.0 & 19.4 & 19.0 & 22.8 & 22.6 \\
\hline Mortgage Guaranty Insurance...$\ldots$. & 26.8 & 27.3 & 27.2 & 27.9 & 26.8 & 27.3 \\
\hline PMI Mortgage Insurance ........ & 12.7 & 12.1 & 13.7 & 13.0 & 12.8 & 12.2 \\
\hline Republic Mortgage Insurance .... & 9.6 & 9.6 & 9.5 & 9.3 & 9.6 & 9.6 \\
\hline Triad Guaranty Insurance $\ldots . \ldots \ldots$ & 1.5 & 1.5 & 1.4 & 1.4 & 1.5 & 1.5 \\
\hline United Guaranty ................. & 12.2 & 12.1 & 12.0 & 12.0 & 12.2 & 12.1 \\
\hline Total & 100.0 & 100.0 & 100.0 & 100.0 & 100.0 & 100.0 \\
\hline $\begin{array}{l}\text { Memo } \\
\text { Number of applications or policies }\end{array}$ & $1,108,512$ & 884,745 & 127,725 & 94,244 & $1,236,237$ & 978,989 \\
\hline
\end{tabular}

Source. Federal Financial Institutions Examination Council.

all regions of the country, although GE Capital's market share was relatively smaller in the West and Mortgage Guaranty's share was relatively large in the Midwest (table A.2, upper panel). Smaller firms generally had a more regional orientation, with Amerin Guaranty more active in the West and Triad Guaranty Insurance Corporation and Republic Mortgage Insurance more active in the South (table A.2, lower panel).
Most loans backed by private mortgage insurance in 1995 were for amounts of less than $\$ 150,000$ (table A.3). More than 90 percent of all mortgages backed by private mortgage insurance were at or below the loan size limits established for Fannie Mae and Freddie Mac (memo, size conformance items). The average size of the home purchase mortgages backed by private mortgage insurance was $\$ 112,546$ and that of the refinancings was $\$ 128,027$.

A.2. PMI policies written for home purchase and refinance loans, distributed by insurance company and by region of the country, 1995

Percent

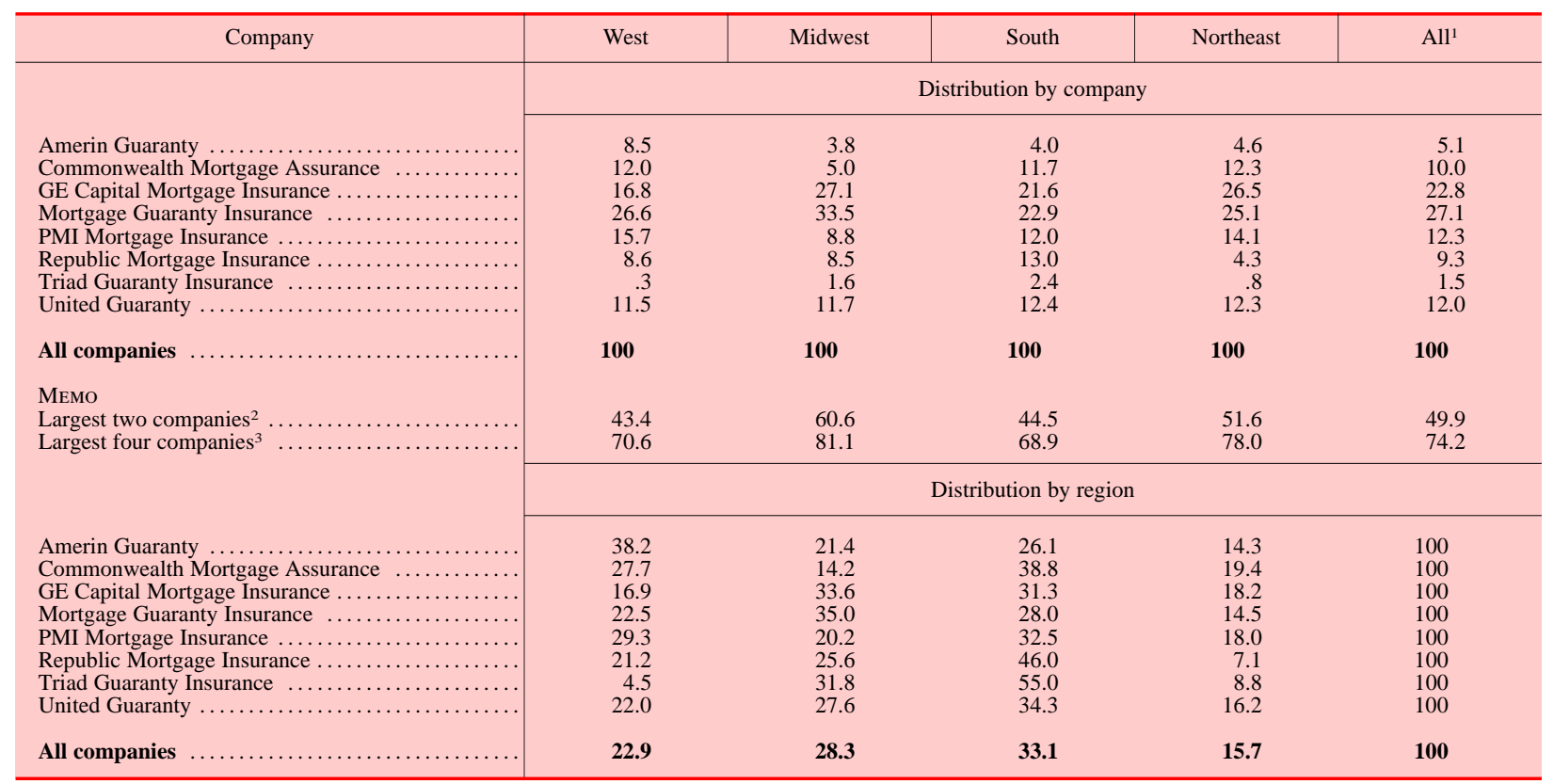

Note. Regions are defined by the Bureau of the Census and contain only whole states; see U.S. Department of Commerce, Statistical Abstract of the United States: 1995 (Government Printing Office, 1995), map on inside front cover.

1. Row totals differ from those shown in table A.1 because information on region was not available for all PMI policies.
2. Mortgage Guaranty Insurance and GE Capital Mortgage Insurance. 3. Mortgage Guaranty Insurance, GE Capital Mortgage Insurance, PMI Mortgage Insurance, and United Guaranty.

Source. Federal Financial Institutions Examination Council. 
A.3. PMI-insured loans, grouped by purpose of loan and distributed by size of loan, 1995

\begin{tabular}{|c|c|c|c|c|c|c|}
\hline \multirow{3}{*}{$\begin{array}{l}\text { Size of loan } \\
\text { (dollars) }\end{array}$} & \multicolumn{3}{|c|}{ Home purchase } & \multicolumn{3}{|c|}{ Home refinance } \\
\hline & \multicolumn{2}{|c|}{ Privately insured } & \multirow{2}{*}{$\begin{array}{l}\text { Memo: All }{ }^{1} \\
\text { (percent) }\end{array}$} & \multicolumn{2}{|c|}{ Privately insured } & \multirow{2}{*}{$\underset{\text { (percent) }}{\text { Memo: All }}$} \\
\hline & Number & Percent & & Number & Percent & \\
\hline Less than 50,000 & 84,372 & 9.5 & 25.9 & 4,122 & 4.4 & 30.9 \\
\hline $50,000-74,999 \ldots$ & 161,517 & 18.3 & 17.3 & 14,502 & 15.4 & 19.7 \\
\hline $75,000-99,999$ & 174,314 & 19.7 & 14.9 & 16,890 & 17.9 & 14.1 \\
\hline $100,000-149,999$ & 277,400 & 31.4 & 22.5 & 31,168 & 33.1 & 17.5 \\
\hline $150,000-199,999$ & 119,686 & 13.5 & 10.2 & 16,466 & 17.5 & 8.4 \\
\hline 200,000 or more. & 67,456 & 7.6 & 9.2 & 11,096 & 11.8 & 9.3 \\
\hline Total & 884,745 & 100.0 & 100.0 & 94,244 & 100.0 & 100.0 \\
\hline \multicolumn{7}{|l|}{ МЕмо } \\
\hline Size conformance $e^{2}$ & & & & & & \\
\hline Conforming ...... & 830,398 & 93.9 & 92.6 & 85,218 & 90.4 & 92.4 \\
\hline Nonconforming .. & 54,347 & 6.1 & 7.4 & 9,026 & 9.6 & 7.6 \\
\hline \multicolumn{7}{|l|}{ Size statistic $(\text { dollars })^{3}$} \\
\hline Mean ............... & \multicolumn{2}{|c|}{112,546} & 102,591 & \multicolumn{2}{|c|}{128,027} & 98,600 \\
\hline Median...$\ldots \ldots \ldots$ & \multicolumn{2}{|c|}{103,000} & 85,000 & \multicolumn{2}{|c|}{117,000} & 73,000 \\
\hline
\end{tabular}

Compared with all conventional home mortgages in 1995 (table A.3, memo, size statistic items), conventional mortgages involving private mortgage insurance were, on average, larger for both home purchase loans and refinancings. In particular, PMI companies insured a much smaller proportion of mortgages under $\$ 50,000$, partly because this size category includes loans for mobile homes, which are covered in the conventional home mortgage data reported under HMDA but are rarely insured by the PMI industry.

\section{Characteristics of Applicants for Private Mortgage Insurance}

In 1995, well over half of all applicants for private mortgage insurance had incomes at or above the median for the MSA in which the property securing the loan was located (table A.4). The distributions of PMI applicants by income differed between those seeking insurance for loans to purchase homes and those applying for insurance to refinance an existing loan. In particular, the proportion of insurance applicants for refinancings who were in the highest income grouping (income 120 percent or more of their MSA median family income) was significantly larger (59 percent) than the comparable proportion of insurance applicants for home purchase mortgages (49 percent). This difference likely reflects the higher proportion of first-time, and perhaps younger, homebuyers in the home purchase category.

Like the distribution of applicants for conventional home purchase loans and refinancings observed in the 1995 HMDA data, most of the applicants for loans backed by PMI were white (about 80 percent) and about half of the applicants were seeking insurance for mortgages to be secured by properties located in predominantly white neighborhoods (neighborhoods with a minority population of less than 10 percent). Overall, about 60 percent of the applicants were seeking insurance to help buy a home or to refinance a mortgage on a property located in the non-central city portion of MSAs.

The distribution of applications to individual PMI companies by applicant income and race or ethnic group generally reflects the aggregate industry distribution (compare table A.4 with table A.5). The differences among the companies were small in most cases and may, in part, reflect differences in regional focus or business orientation from company to company.

\section{Disposition of Applications for Private Mortgage Insurance}

PMI companies approved most of the insurance applications on which they acted during 1995roughly 87 percent of applications to back home purchase loans and 85 percent for refinancings (table A.6). Of the applications for insurance on home purchase loans, 9.3 percent were denied by a PMI company and 2.6 percent were withdrawn by the lender; in a relatively small percentage of cases, the application file was closed after additional information needed by a PMI company to make a decision was not provided. For home refinancing applications, the denial rate was 11.5 percent and the withdrawal 
rate was 3.2 percent. The denial rate for applications to insure mortgages for home purchases was little changed from 1994, while the denial rate for refinancings increased, from 8.5 percent to 11.5 percent.

High approval rates for PMI applications are not surprising: Lenders know the prospective borrowers' credit circumstances and the credit underwriting guidelines used by the PMI companies and, therefore, submit only those applications they expect to be approved. ${ }^{28}$ However, the evaluation of disposition patterns for mortgage insurance applications is complicated because lenders may submit an application

28. Also, PMI companies are increasingly delegating decisions about applications to the lending institutions. In such cases, the PMI company becomes aware of an application for insurance only when a lender has selected it as the insurance provider. In fact, nearly all of the business of one PMI company, Amerin Guaranty Corporation, is based on decisions delegated to lenders. for insurance to more than one PMI company at a time. Multiple applications are potentially more common for private mortgage insurance than for mortgages because PMI companies do not charge for PMI applications whereas lenders generally charge for mortgage applications.

Overall, nearly 6 percent of the applications in the 1995 data appear to have involved multiple applications (see box "Multiple Applications"). Analysis suggests that it was mainly the applications of marginally qualified applicants that were submitted to more than one PMI company. For example, among the multiple applications, the denial rate was roughly 40 percent for insurance for home purchase mortgages, compared with 7 percent for all home purchase applications excluding the multiple applications (the denial rate for all home purchase applications, 9.3 percent, is shown in table A.6).

A.4. PMI applications, grouped by purpose of loan and distributed by characteristics of applicant and of census tract in which property is located, 1995

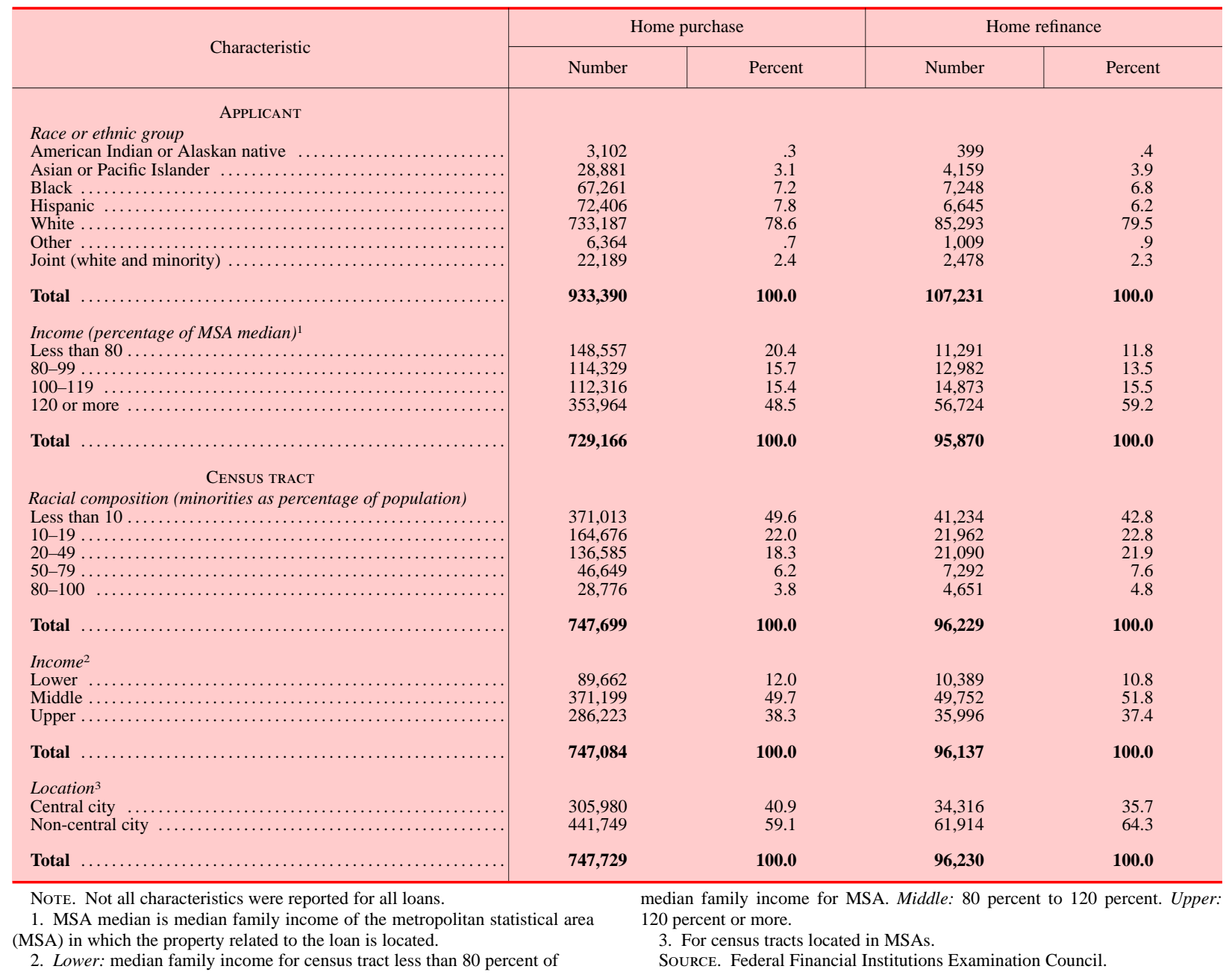


A.5. PMI applications, grouped by insurance company and purpose of loan and distributed by characteristics of applicant and census tract in which property is located, 1995

Percent

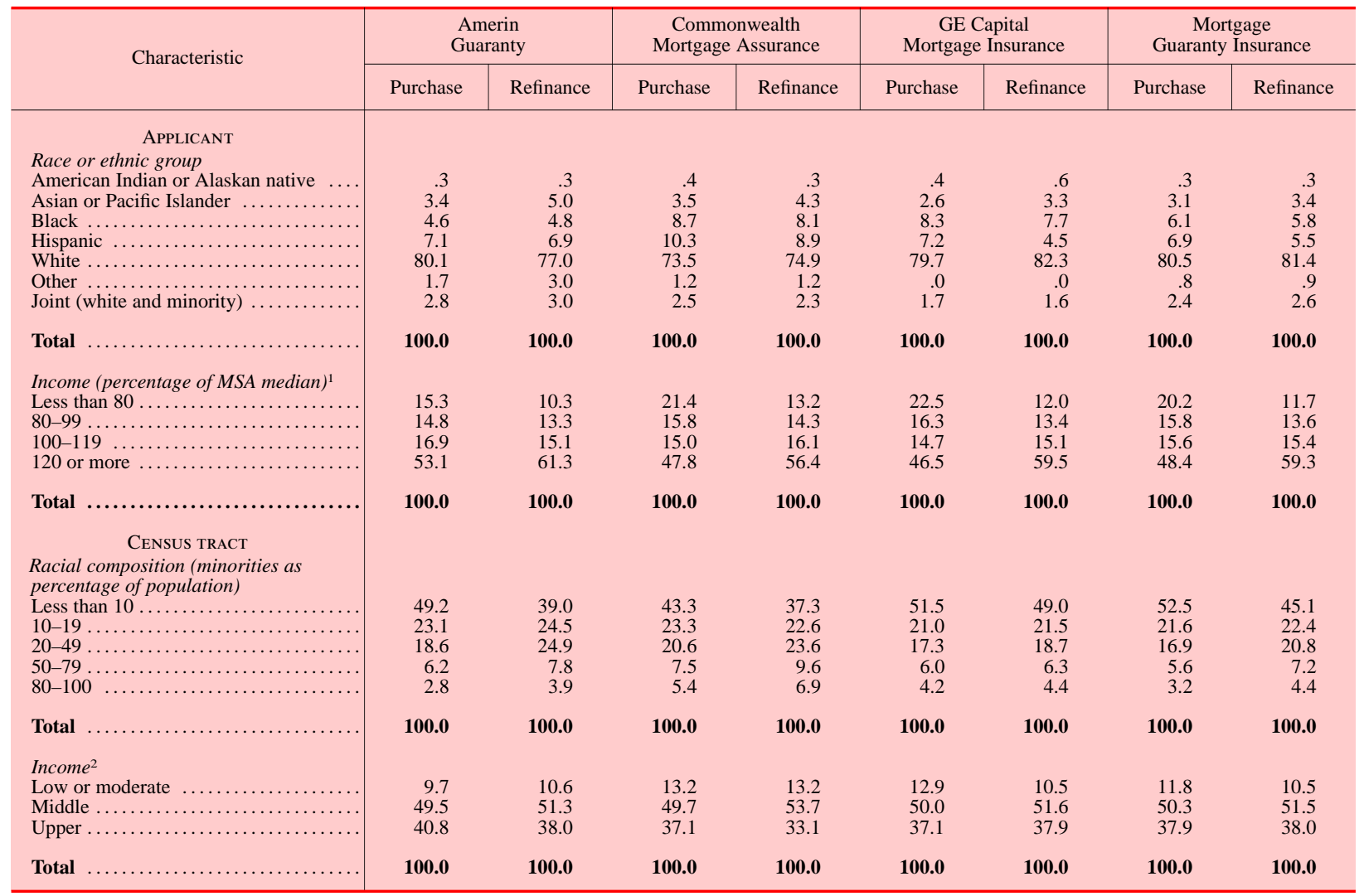

Although most 1995 applications for private mortgage insurance were approved, there were substantial differences across metropolitan areas. In particular, applications for insurance for home purchase mortgages secured by properties located in nearly all California MSAs and in a number of Florida MSAs had relatively high denial rates. These elevated denial rates continue the pattern first observed in the 1993 PMI data. In California, weak housing markets combined with the aggressive pursuit of customers by mortgage originators may have led to higher proportions of marginally qualified applicants for mortgage insurance in these markets. The explanations for high denial rates in Florida are less certain; possibilities include a high proportion of relatively risky types of property (condominiums and second homes) and a local economy that is prone to greater volatility in housing prices. In contrast, many MSAs in the Midwest and some in the South had denial rates well below the 8.2 percent national average for MSAs (for example, Raleigh-Durham, 2.6 percent;
Minneapolis-St. Paul, 3.3 percent; Kansas City, 3.5 percent; Indianapolis, 4.5 percent; Richmond, 4.5 percent; and St. Louis, 4.5 percent).

\section{Disposition by Applicant Characteristics}

In general, the amount, source, and stability of income can be expected to affect an applicant's ability to qualify for mortgage insurance, although these aspects of income are usually considered in relation to the applicant's existing and proposed debt burden rather than as absolute measures of creditworthiness. Other factors considered in evaluating creditworthiness include the amount of assets available to meet down payment and closing cost requirements, employment experience, and credit history. On average, lower-income households have fewer assets and lower net worth and experience more frequent employment disruptions than do higher-income households; this combination of factors often results in denial of an application. 


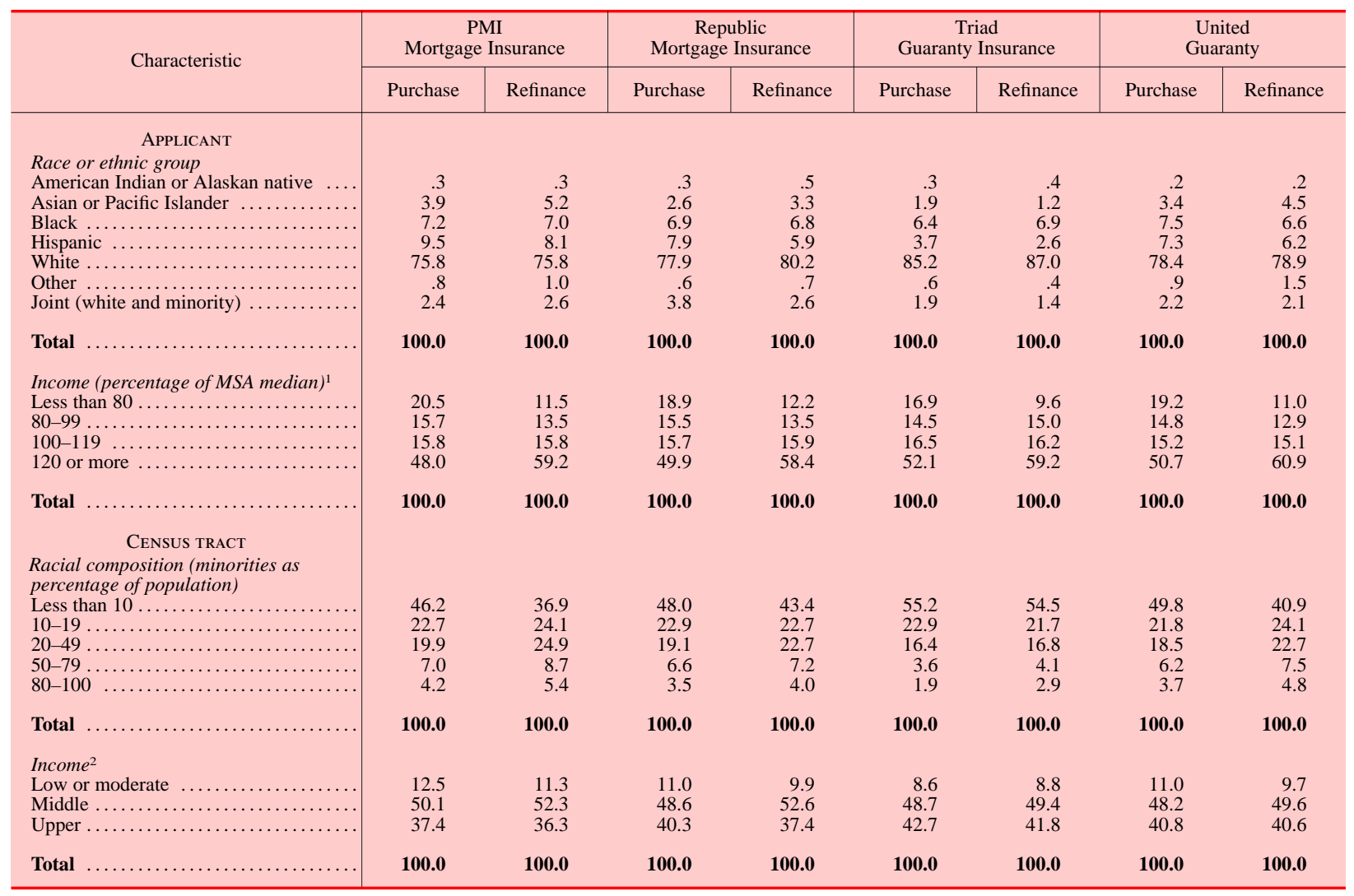

1. MSA median is median family income of the metropolitan statistical area (MSA) in which the property related to the loan is located.

2. Low or moderate: median family income for census tract less than

80 percent of median family income for MSA of tract. Middle income: 80 percent to 120 percent. Upper income: 120 percent or more.

Source. Federal Financial Institutions Examination Council.

The 1995 data indicate that most applications for private mortgage insurance were approved but that the rates of approval and denial varied among applicants grouped by income (table A.6). For example, 90 percent of the applicants for insurance for home purchase loans whose incomes placed them in the highest income group were approved for insurance, compared with 83 percent in the lowest income group (income less than 80 percent of their MSA median). The same pattern was found for applications for insurance of refinancings.

Examination of the racial or ethnic characteristics of applicants indicates that greater proportions of Asian, black, and Hispanic applicants than of white applicants had their applications for private mortgage insurance denied in 1995; the denial rate for Native American applicants was about the same as that for white applicants. For example, for insurance for home purchase loans, 13.8 percent of Asian applicants, 19.3 percent of black applicants, 17.6 percent of Hispanic applicants, 10.5 percent of Native Ameri- can applicants, and 8.5 percent of white applicants were denied. The rate of denial also generally increased as the proportion of minority and lowerincome residents in a neighborhood increased.

Differences in PMI denial rates for applicants grouped by race or ethnicity reflect various factors, including the proportion of each group with relatively low incomes. In 1995, 19 percent of the white applicants who applied for insurance to back home purchase loans had incomes that were less than 80 percent of the median family income for their MSA (data not shown in tables). The figures for other groups of applicants in the same income category were roughly 40 percent for black, 35 percent for Hispanic, and 18 percent for Asian applicants. Differences in the distribution of applicants for insurance by income account for some of the differences in denial rates. However, within each income group, white applicants had lower rates of denial than Asian, black, or Hispanic applicants (table A.7). 


\section{Multiple Applications}

Of the 1,108,512 applications for insurance for home purchase loans in $1995,65,714$ (5.9 percent) appear to have been multiple applications, and of the 127,725 applications for insurance to back refinancings that year, 7,313 (5.7 percent) appear to have been multiple applications. ${ }^{1}$ Multiple applications were identified through a search of the data for applications showing identical census tracts, purposes of loan, and race or ethnic status and similar applicant incomes and loan sizes. (For applicant income and loan size, differ-

1. Most matches were of two applications, indicating that a given application was typically not submitted to more than two PMI companies. ences of $\$ 1,000$ or less were allowed.) If two applications appeared to match but both were reported to have been backed by insurance, the applications were assumed not to be duplicates. Applications from Hispanic, black, and Asian applicants-and from applicants not in the highest income category-were more likely than applications from would-be borrowers in other racial or ethnic categories to be sent to more than one PMI company (compare table A.4 with the table below). In addition, denial rates were substantially higher for all categories of applicants with multiple application records (compare table A.6 with the table below).

Distribution and denial rate for PMI applications sent to more than one company, by purpose of loan and characteristics of applicant and of census tract in which property is located, 1995

Percent

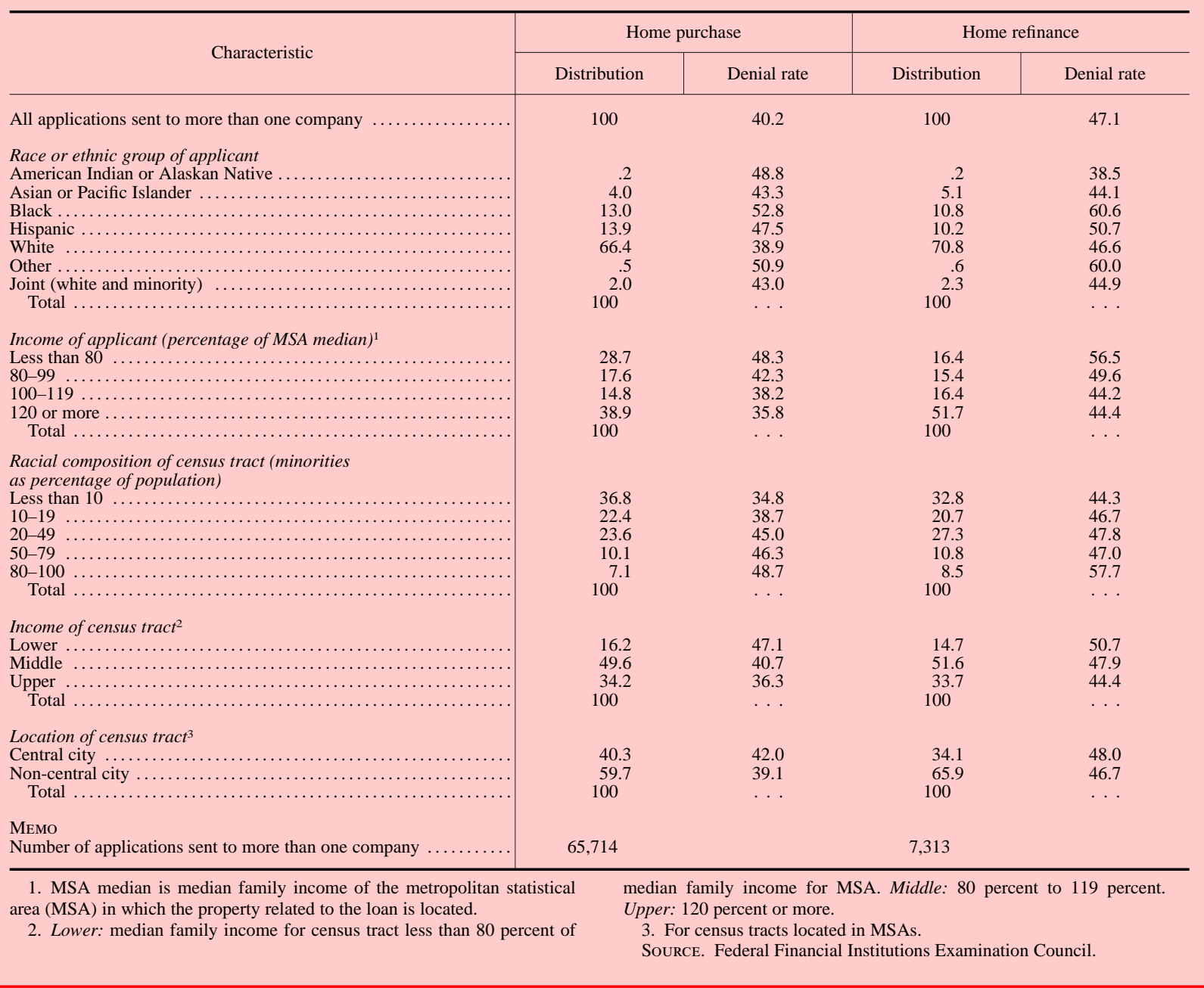


Denial rates are also explained in part by differences across racial and ethnic groups in the frequency of multiple applications for insurance by the same applicants. Generally, applications by minorities are more likely to be submitted to more than one PMI company because minority applicants tend to have lower incomes or more complex credit circumstances. Excluding multiple applications submitted for the same individuals reduces denial rates 3 to 4 percentage points for minorities and less than 2 percentage points for whites.

The pattern of denial rates by race or ethnicity differs from the pattern in the HMDA data in one notable way: In the HMDA data, Asian applicants for home purchase loans have a lower denial rate than do white applicants. ${ }^{29}$ The high proportion of Asian

29. For example, according to the 1995 HDMA data, the denial rate for home purchase mortgages was 12.5 percent for Asian applicants and 20.6 percent for white applicants. applicants in California may help account for their relatively high denial rate for private mortgage insurance. Among Asians applying for home purchase loans with insurance (where the MSA location of the property was reported), 39 percent were seeking to buy homes in California. In contrast, only 11 percent of all PMI applications were for loans to buy homes in California. Slightly more than 20 percent of the Asian applicants in California were denied private mortgage insurance, compared with only 8 percent of Asian applicants outside California (data not shown in tables).

The difference in PMI denial rates between white applicants and black and Hispanic applicants may lead some observers to conclude that race influences the disposition of applications. However, because PMI companies do not have direct contact with prospective borrowers, they would be aware of race or ethnic identities only from the application. Although these disparities raise questions, the extent of any

A.6. PMI applications, grouped by characteristics of applicant and of census tract in which property is located and distributed by purpose and disposition of application, 1995

Percent

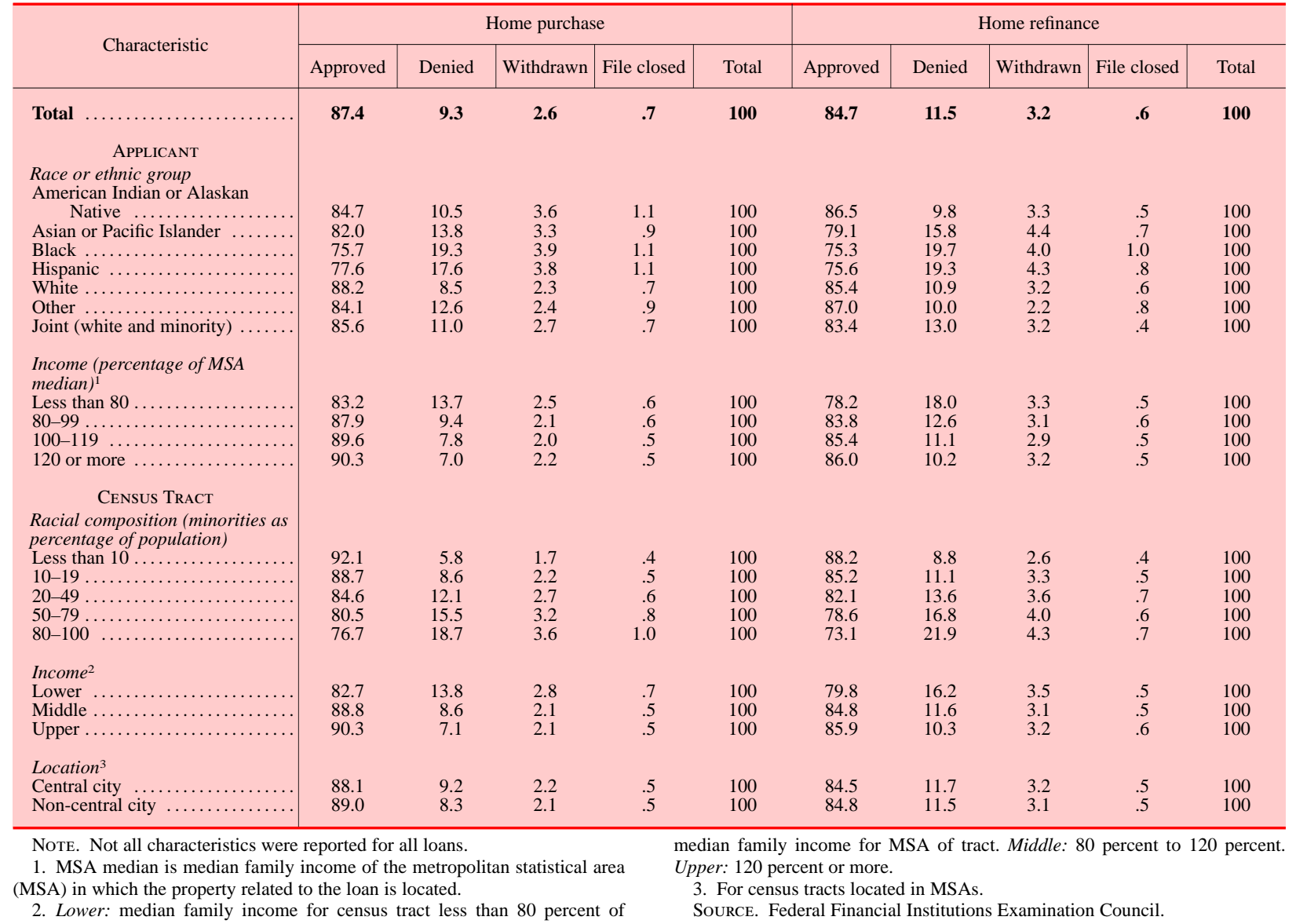


A.7. PMI applications, grouped by purpose and disposition of application, 1995 Percent

\begin{tabular}{|c|c|c|c|c|c|c|c|c|c|c|}
\hline \multirow{2}{*}{$\begin{array}{l}\text { Applicant's MSA-relative income } \\
\text { and race or ethnic group }{ }^{1}\end{array}$} & \multicolumn{5}{|c|}{ Home purchase } & \multicolumn{5}{|c|}{ Home refinance } \\
\hline & Approved & Denied & Withdrawn & File closed & Total & Approved & Denied & Withdrawn & File closed & Total \\
\hline \multicolumn{11}{|l|}{ Less than 80 percent } \\
\hline American Indian or Alaskan native & 84.7 & 12.2 & 2.7 & .4 & 100 & 82.0 & 16.0 & 2.0 & .0 & 100 \\
\hline Asian or Pacific Islander ............. & 80.4 & 16.2 & 2.8 & .6 & 100 & 73.8 & 22.4 & 2.8 & 1.0 & 100 \\
\hline 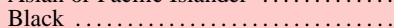 & 73.5 & 22.2 & 3.5 & .8 & 100 & 69.3 & 26.4 & 3.8 & 4 & 100 \\
\hline Hispanic $\ldots \ldots \ldots \ldots \ldots \ldots$ & 76.9 & 19.3 & 3.1 & .8 & 100 & 70.0 & 24.8 & 4.5 & .8 & 100 \\
\hline White ... & 85.3 & 11.9 & 2.3 & .5 & 100 & 79.6 & 16.8 & 3.0 & .6 & 100 \\
\hline Other $\ldots \ldots \ldots \ldots \ldots \ldots \ldots$ & 81.8 & 15.7 & 1.8 & .6 & 100 & 81.9 & 14.9 & 3.2 & .0 & 100 \\
\hline Joint (white and minority) .... & 79.5 & 17.7 & 2.1 & .7 & 100 & 72.3 & 25.2 & 2.5 & .0 & 100 \\
\hline \multicolumn{11}{|l|}{ 80-99 percent } \\
\hline American Indian or Alaskan native & 87.1 & 9.7 & 2.1 & 1.2 & 100 & 82.9 & 17.1 & .0 & .0 & 100 \\
\hline Asian or Pacific Islander ........... & 84.0 & 12.6 & 2.9 & .5 & 100 & 77.8 & 17.6 & 4.3 & .2 & 100 \\
\hline Black $\ldots \ldots \ldots \ldots \ldots \ldots$ & 78.4 & 17.3 & 3.5 & .9 & 100 & 75.6 & 18.3 & 4.4 & 1.7 & 100 \\
\hline Hispanic ......... & 78.3 & 17.6 & 3.2 & .9 & 100 & 76.1 & 19.3 & 4.2 & .5 & 100 \\
\hline White .......... & 89.7 & 7.9 & 1.9 & .5 & 100 & 84.9 & 11.8 & 2.8 & .5 & 100 \\
\hline Other $\ldots \ldots \ldots \ldots \ldots \ldots \ldots$ & 84.2 & 14.0 & 1.4 & .4 & 100 & 87.4 & 6.8 & 3.9 & 1.9 & 100 \\
\hline Joint (white and minority) .. & 86.8 & 11.0 & 1.7 & .5 & 100 & 79.6 & 16.9 & 3.0 & .5 & 100 \\
\hline \multicolumn{11}{|l|}{ 100-119 percent } \\
\hline American Indian or Alaskan native & 87.6 & 8.6 & 3.2 & 6 & 100 & 88.6 & 6.8 & 2.3 & 2.3 & 100 \\
\hline Asian or Pacific Islander $\ldots . \ldots \ldots \ldots$ & 83.8 & 12.8 & 2.7 & .8 & 100 & 82.2 & 12.4 & 4.9 & .5 & 100 \\
\hline 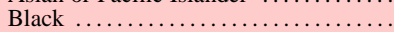 & 79.4 & 16.6 & 3.2 & .7 & 100 & 75.4 & 19.3 & 3.7 & 1.5 & 100 \\
\hline Hispanic $\ldots \ldots \ldots \ldots \ldots \ldots \ldots$ & 79.3 & 16.1 & 3.6 & 1.0 & 100 & 76.7 & 17.6 & 4.5 & 1.1 & 100 \\
\hline White $\ldots \ldots \ldots \ldots \ldots \ldots \ldots \ldots \ldots$ & 91.2 & 6.5 & 1.8 & .4 & 100 & 86.5 & 10.5 & 2.5 & .5 & 100 \\
\hline Other $\ldots \ldots \ldots \ldots \ldots \ldots$ & 87.2 & 9.6 & 2.3 & .8 & 100 & 89.1 & 9.4 & .7 & .7 & 100 \\
\hline Joint (white and minority) & 87.6 & 9.9 & 2.0 & .6 & 100 & 84.7 & 12.9 & 2.4 & .0 & 100 \\
\hline \multicolumn{11}{|l|}{120 or more percent } \\
\hline American Indian or Alaskan native & 87.1 & 8.5 & 3.4 & 1.0 & 100 & 86.6 & 7.5 & 5.3 & .5 & 100 \\
\hline Asian or Pacific Islander .......... & 82.5 & 13.1 & 3.5 & .9 & 100 & 78.7 & 15.7 & 4.8 & .7 & 100 \\
\hline Black $\ldots \ldots \ldots \ldots \ldots$ & 81.2 & 14.8 & 3.2 & .8 & 100 & 75.9 & 19.6 & 3.9 & .6 & 100 \\
\hline Hispanic $\ldots \ldots \ldots \ldots \ldots \ldots \ldots \ldots$ & 81.4 & 14.1 & 3.5 & 1.0 & 100 & 77.1 & 17.8 & 4.1 & .9 & 100 \\
\hline White $\ldots \ldots \ldots \ldots \ldots \ldots \ldots \ldots \ldots \ldots \ldots \ldots$ & 91.1 & 6.3 & 2.1 & .5 & 100 & 86.7 & 9.7 & 3.1 & .5 & 100 \\
\hline Other $\ldots \ldots \ldots \ldots \ldots \ldots$ & 86.7 & 10.1 & 2.5 & .6 & 100 & 86.4 & 10.6 & 2.2 & .8 & 100 \\
\hline Joint (white and minority) & 88.3 & 8.7 & 2.5 & .6 & 100 & 84.8 & 11.9 & 3.1 & .2 & 100 \\
\hline
\end{tabular}

1. Income percentages are the percentages of the median family income of the MSA in which the property related to the loan is located.

discrimination cannot be determined from the data submitted by the PMI companies because the companies provide little information about the characteristics of the properties that applicants seek to purchase or refinance or of the financial circumstances of the applicants. For example, applicants' levels of debt, their credit histories, and their employment experiences are not disclosed. Without information about these circumstances and about the specific underwriting standards used by PMI companies, the fairness of the decision process cannot be assessed.

\section{APPENDIX B:}

\section{ADJUSTING THE COMPOSITION OF MORTGAGE ACTIVITY FOR CREDIT RISK}

The process of converting dollar amounts of mortgages extended or insured ("unadjusted dollars") to risk dollars - the long-term expected loss for each mortgage extended-involved four steps: (1) the use of econometric and institutional information about loan-to-value ratio (LTV) distributions to create such distributions for each type of institution; (2) incorpo- ration of our PMI matching procedure, modified by institutional information, to determine the extent of PMI use across institutions; (3) application of historical default rates and loss severity rates by loan-tovalue ratio for each type of institution to calculate the estimated risk dollars held by each group of institutions; and (4) reallocation of these risk dollars across institutions to account for risk-sharing arrangements between private mortgage insurers and other institutions and between the VA and originators of VA mortgages.

\section{Estimating Loan-to-Value Distributions}

For most institutions, the distribution of loan-to-value ratios for their mortgage portfolios was not publicly available. Therefore, we developed a model for estimating LTVs for home purchase loans reported in the 1995 HMDA data using preliminary information from the Federal Reserve's 1995 Survey of Consumer Finances (details of this procedure are available upon request from the authors). For some of the institutions for which exact aggregate LTV distribu- 
tions were available, we adjusted our estimates to reflect those figures.

Our estimates, together with institutional knowledge, suggest that there are essentially five different distributions of loan-to-value ratios across mortgage holders and insurers (table B.1). The FHA, the VA, Fannie Mae and Freddie Mac, and the PMI companies appear to have LTV distributions significantly different from each other. But the fifth groupdepository institutions subject to the Community Reinvestment Act, mortgage bankers, other privately chartered nondepository institutions, and credit unions-appear to differ little from each other. We estimated econometrically that roughly 60 percent of the mortgages held by this latter group have loan-tovalue ratios of 80 percent or less, 20 percent have ratios between 80 percent and 90 percent, and 20 percent have ratios greater than 90 percent.

Because data on LTV distributions for this fifth group of institutions were not available, we had no way of directly evaluating the validity of our estimates. However, aggregate data were available for insured and uninsured conventional home purchase mortgages originated by depository institutions and mortgage bankers as a group. ${ }^{30}$ Those data suggest that our estimates underpredicted the proportion in the lowest LTV category but were close to correct for the highest LTV category (table B.2).

For insured mortgages, the distribution of LTVs varies by insurer. Generally, government-insured loans have very high concentrations of mortgages having loan-to-value ratios of 90 percent or higher; we estimated that 93 percent of the loans insured by the VA in 1995 were in this category. In contrast, privately insured mortgages were estimated to be

30. These data are gathered in the Mortgage Interest Rate Survey (MIRS), a monthly survey conducted by the Federal Housing Finance Board. The Finance Board provided us with annual data for 1995.

B.1. Estimated loan-to-value ratios, default rates, loss severity rates, and risk-sharing proportions used to derive expected losses on mortgages extended in 1995

Percent

\begin{tabular}{|c|c|c|c|c|c|c|c|c|c|c|c|c|c|c|}
\hline \multirow{3}{*}{$\begin{array}{l}\text { Insurance status } \\
\text { and type of risk holder }\end{array}$} & \multicolumn{5}{|c|}{ Estimated loan-to-value ratio (percent) } & \multicolumn{4}{|c|}{$\begin{array}{l}\text { Estimated default rate, } \\
\text { by loan-to-value ratio }{ }^{1}\end{array}$} & \multicolumn{4}{|c|}{$\begin{array}{c}\text { Estimated loss severity rate, } \\
\text { by loan-to-value ratio }{ }^{2}\end{array}$} & \multirow{3}{*}{$\begin{array}{c}\text { Memo: } \\
\text { Estimated } \\
\text { expected } \\
\text { cumulative } \\
\text { dollar loss } \\
\text { per } \$ 100 \text { o } \\
\text { mortgages } \\
\text { extended by } \\
\text { institution }\end{array}$} \\
\hline & \multirow{2}{*}{$\begin{array}{l}80 \text { or } \\
\text { less }\end{array}$} & \multirow{2}{*}{$81-90$} & \multicolumn{2}{|c|}{91 or more } & \multirow{2}{*}{ Total } & \multirow{2}{*}{$\begin{array}{l}80 \text { or } \\
\text { less }\end{array}$} & \multirow{2}{*}{$81-90$} & \multicolumn{2}{|c|}{91 or more } & \multirow{2}{*}{$\begin{array}{l}80 \text { or } \\
\text { less }\end{array}$} & \multirow{2}{*}{$81-90$} & \multicolumn{2}{|c|}{91 or more } & \\
\hline & & & $91-95$ & $\begin{array}{l}96 \text { or } \\
\text { more }\end{array}$ & & & & $91-95$ & $\begin{array}{l}96 \text { or } \\
\text { more }\end{array}$ & & & $91-95$ & $\begin{array}{l}96 \text { or } \\
\text { more }\end{array}$ & \\
\hline \multicolumn{15}{|l|}{ INSURED MORTGAGES } \\
\hline FHA $\ldots \ldots \ldots \ldots \ldots \ldots$ & 6 & 27 & 31 & 36 & 100 & 5.2 & 10.6 & 12.4 & 15.5 & 45.8 & 44.9 & 46.8 & 56.6 & 6.38 \\
\hline & 1 & 6 & 17 & 76 & 100 & 1.1 & 3.5 & 6.6 & 12.2 & 45.8 & 44.9 & 46.8 & 56.6 & 4.70 \\
\hline Private mortgage insurers ${ }^{4}$ & 2 & 48 & 47 & 3 & 100 & .8 & 2.7 & 6.2 & 9.6 & 28.4 & 34.4 & 47.9 & 47.9 & 1.09 \\
\hline UNINSURED MORTGAGES & & & & & & & & & & & & & & \\
\hline Fannie Mae or Freddie Mac & 96 & 2 & & 2 & 100 & .8 & 2.7 & & 6.2 & 28.4 & 34.4 & 4 & & .59 \\
\hline $\begin{array}{l}\text { Depositories subject to } \\
\text { CRA }^{5} \ldots \ldots \ldots \ldots\end{array}$ & 61 & 19 & & 20 & 100 & .8 & 2.7 & & 6.2 & 28.4 & 34.4 & & & .94 \\
\hline Independent mortgage & & & & & & & & & & & & & & \\
\hline $\begin{array}{l}\text { companies }^{6} \cdot \ldots \\
\text { Other }^{7}\end{array}$ & $\begin{array}{l}63 \\
61\end{array}$ & $\begin{array}{l}18 \\
19\end{array}$ & & 19 & $\begin{array}{l}100 \\
100\end{array}$ & $\begin{array}{l}.8 \\
.8\end{array}$ & $\begin{array}{l}2.7 \\
2.7\end{array}$ & & 6.2 & $\begin{array}{l}28.4 \\
28.4\end{array}$ & $\begin{array}{l}34.4 \\
34.4\end{array}$ & & & $\begin{array}{l}1.04 \\
1.23\end{array}$ \\
\hline Credit unions . & 62 & 19 & & 19 & 100 & .8 & 2.7 & & 6.2 & 28.4 & 34.4 & & & .91 \\
\hline All risk holders & $\ldots$ & $\cdots$ & . & $\cdots$ & $\cdots$ & .. & $\cdots$ & & .. & $\cdots$ & $\cdots$ & $\ldots$ & $\cdots$ & 2.90 \\
\hline \multicolumn{15}{|l|}{$\begin{array}{l}\text { Proportion of risk borne } \\
\text { by insurer under } \\
\text { risk-sharing arrangements }\end{array}$} \\
\hline Private mortgage insurers .. & 50 & 50 & & 50 & 60 & $\cdots$ & $\cdots$ & ... & . & & . & & . & $\cdots$ \\
\hline & 80 & 80 & & 80 & 80 & . & . & & & & & & & \\
\hline
\end{tabular}

1. Default rates show the percentage of mortgages originated in 1975-83 that had defaulted by the end of 1992 .

2. Total loss before mortgage insurance payout resulting from foreclosure (if any) divided by original mortgage amount.

3. Covers both insured and uninsured mortgages. Derived by multiplying default rate by loss severity rate within each loan-to-value range and then summing across loan-to-value ranges weighted by the dollar proportion of an institution's mortgages in that category. Losses were then reallocated among institutions using risk-sharing rules. Losses are cumulative over ten to eighteen years, based on mortgages originated during 1975-83 and tracked through 1992 .

4. Based on discussions with individuals at private mortgage insurance companies. The default rate for the LTV range "96 or more" was estimated using the relationship between default rates for FHA and VA loans in the two highest LTV ranges.
5. Includes mortgages originated and held in portfolio by commercial banks and savings associations and their mortgage company affiliates and mortgages sold to commercial banks and savings associations.

6. Includes mortgages originated and held in portfolio by independent mortgage companies and mortgages sold to affiliates by independent mortgage companies.

7. Includes mortgages sold to life insurance companies, pension funds, and other private-sector purchasers.

. Not applicable.

Source. Federal Housing Administration, U.S. Department of Veterans Affairs, Freddie Mac, 1995 Survey of Consumer Finances, and discussions with individuals at private mortgage insurance companies. 
more concentrated in the 80 percent to 90 percent LTV range.

For FHA- and VA-insured mortgages, our econometric estimates were close to the actual aggregate distributions (table B.2). We used our estimates for calculating risk dollars for FHA and VA loans because our model allows us to vary LTV by income and race or ethnic group in a consistent manner. For privately insured mortgages, discussions with industry representatives and information available from annual reports and the trade press indicated that our model significantly overpredicted the proportion of mortgages in the lowest LTV category and underpredicted the proportion in the higher categories. Instead of using the model's prediction, we imposed an LTV distribution based on our information about the industry. However, we applied the model to suggest the extent of variation in the LTV distribution across groups by income and race or ethnic status.

For mortgages purchased by Fannie Mae and Freddie Mac, the model significantly underpredicted the actual proportion of uninsured mortgages in the lowest LTV category (table B.2). This underprediction may not be surprising because the Survey of Consumer Finances does not distinguish between mortgages that are sold and those that the originator keeps in its portfolio, and thus the model cannot account for this type of variation across institutions.

As discussed earlier, Fannie Mae and Freddie Mac generally are not allowed to purchase mortgages with LTVs above 80 percent unless the mortgage is backed by private mortgage insurance or the buyer has recourse to the lender. Almost all of these high-LTV mortgages have private mortgage insurance, so only a small proportion of uninsured mortgages purchased by Fannie Mae and Freddie Mac have LTVs above 80 percent. For uninsured mortgages purchased by Fannie Mae and Freddie Mac, we used a distribution based on information from knowledgeable industry sources. As we did for the PMI industry, we used the model to vary Fannie Mae's and Freddie Mac's LTV distributions across groups by income or by race or ethnic status.

\section{Adjusting for Private Mortgage Insurance}

The second step in calculating risk dollars was to adjust our estimates of the extent of private mortgage insurance coverage among conventional home purchase mortgages. Our matching of PMI records to HMDA records probably significantly undercounted the number of mortgages with private mortgage insurance. The exact proportion of mortgages origi- nated in a given year that are covered by private mortgage insurance is unknown. However, the extent of the undercount for mortgages purchased by Fannie Mae and Freddie Mac is known. Thus, for our estimates of the distribution of risk dollars across types of institutions, we increased the estimated number of mortgages backed by private insurance for all institutions in proportion to the known undercount for Fannie Mae's and Freddie Mac's 1995 home purchase mortgages.

\section{Applying Default Rates and Loss Severity Rates}

In the third step we converted dollars of mortgages extended into expected losses by applying average default and loss severity rates. The rates we used were for mortgages originated from 1975 through 1983, with performance measured through the end of 1992. The data came from three sources: Freddie Mac, the FHA, and the VA. Default and loss severity rates for Freddie Mac, which represent a large number of conventional home mortgages but not nonconforming mortgages, were used to calculate credit risk in the conventional mortgage system (table B.1). ${ }^{31}$ The appropriateness of applying this single set of rates to all conventional mortgages is unknown; however, only Freddie Mac has made these data public. For the government mortgage system, the FHA and the VA, at our request, provided comparable information on mortgages backed by their insurance programs.

\section{Incorporating Risk-Sharing Relationships}

The final step in calculating risk dollars held by different institutions was to account for risk-sharing arrangements. For privately insured mortgages, we estimated that losses are divided $50-50$ between the insurer and the insuree if the loan-to-value ratio is

31. Information on default and loss severity rates at Freddie Mac was drawn from Robert Van Order and Peter Zorn, "Income, Location and Default: Some Implications for Community Lending," paper presented at the Conference on Housing and Economics, Ohio State University, Columbus, July 1995. Their default and loss severity rates are estimated through 1992; discussions with the authors as well as the FHA and the VA indicate that estimated default and loss severity rates have fallen since 1992 and that the difference between the default rate for high-LTV loans relative to that for lower-LTV loans is currently less than presented in their study. Because all market participants are affected in the same manner by these trends, we have not attempted to update those estimates. 
B.2. Actual and predicted distributions of loan-to-value ratios for mortgages extended in 1995 Percent

\begin{tabular}{|c|c|c|c|c|c|c|c|c|c|c|}
\hline \multirow{3}{*}{$\begin{array}{l}\text { Loan-to-value range } \\
\text { (percent) }\end{array}$} & \multicolumn{2}{|c|}{ FHA mortgages } & \multicolumn{2}{|c|}{ VA mortgages } & \multicolumn{4}{|c|}{ Fannie Mae and Freddie Mac mortgages } & \multicolumn{2}{|c|}{ MIRS mortgages ${ }^{1}$} \\
\hline & \multirow{2}{*}{ Actual } & \multirow{2}{*}{ Predicted } & \multirow{2}{*}{ Actual } & \multirow{2}{*}{ Predicted } & \multicolumn{2}{|c|}{ Insured } & \multicolumn{2}{|c|}{ Uninsured } & \multirow{2}{*}{ Actual } & \multirow{2}{*}{ Predicted } \\
\hline & & & & & Actual & Predicted & Actual & Predicted & & \\
\hline 80 or less & 3 & 6 & 2 & 1 & 0 & 20 & 96 & 59 & 54 & 49 \\
\hline $81-90 \ldots .$. & 12 & 27 & 4 & 6 & 43 & 45 & 2 & 20 & 18 & 26 \\
\hline 91 or more & & & & & 57 & 35 & 2 & 21 & 27 & 25 \\
\hline $91-95 \ldots \ldots$ & 34 & 31 & 7 & 17 & $\ldots$ & $\ldots$ & $\ldots$ & $\ldots$ & $\ldots$ & $\ldots$ \\
\hline 96 or more $\ldots \ldots \ldots \ldots$ & 51 & 36 & 88 & 76 & 8 & . . & $\ldots$ & $\ldots$ & $\ldots$ & $\ldots$ \\
\hline All & 100 & 100 & 100 & 100 & 100 & 100 & 100 & 100 & 100 & 100 \\
\hline
\end{tabular}

1. Data for insured and uninsured conventional home purchase mortgages originated by depository institutions and mortgage bankers as a group. From the Mortgage Interest Rate Survey conducted by the Federal Housing Finance Board.

Source. Federal Housing Administration, Department of Veterans Affairs, and industry sources.
90 percent or less and 60-40 if the loan-to-value ratio is greater than 90 percent. $^{32}$

The VA, like private mortgage insurance companies, provides guarantees that may not cover all the losses associated with mortgage defaults. When a borrower with a VA mortgage defaults, the VA has the option to "put back" the home to the mortgage holder if it calculates that such a "put back" is the least costly means (to the VA) of implementing its guarantee. In recent years the VA has rarely exercised this option, but it was used for roughly one-fifth of VA defaults (measured by the number of loans) during the late 1980s, when home values in some regions of the country declined sharply. Thus, estimates of the long-term credit risk of a VA mortgage must provide for this risk-sharing; we estimated that 80 percent of the losses are borne by the VA and 20 percent by the mortgage originator regardless of loan-to-value ratio.

Commercial banks, savings associations, and mortgage companies are the most frequent users of VA guarantees and thus share risk with the VA to a limited extent. Typically, a VA loan is securitized by Ginnie Mae. For Ginnie Mae-backed securities, the institutions that service the mortgages underlying the securities (that is, collect the mortgage payments and distribute them to the holders of the securities) are usually the institutions that hold the mortgages and thus partly bear the cost of default. However, in some cases the originator of a mortgage (who may or may not be the current servicer) may retain some of the

32. Our estimated sharing rule between PMI companies and other institutions is based on conversations with industry participants and on comparing the PMI coverage rates used by Fannie Mae and Freddie Mac with the historic estimated loss severity rates for mortgages with different LTVs. credit risk of that mortgage. Because we lacked information about which institutions service VA loans, we assumed that the type of institution that originated a VA mortgage, as reported in the HMDA data, was the current servicer of the mortgage and hence bore that portion of the credit risk that was not borne by the VA.

\section{Testing the Robustness of Our Analysis}

We reviewed the effects of varying some of the assumptions and parameters used in our analysis. For example, we varied the LTV distribution for mortgages held by portfolio lenders because we were uncertain about the actual distribution. On one hand, the 1995 Survey of Consumer Finances indicates that 39 percent of the uninsured mortgages had LTVs higher than 80 percent. As Fannie Mae and Freddie Mac purchased very few of these loans, the Survey of Consumer Finances data suggest that an even greater proportion of the uninsured mortgages held by portfolio lenders had an LTV higher than 80 percent.

On the other hand, depository institutions have a strong incentive to hold only mortgages that have an LTV of 80 percent or less or that are covered by private mortgage insurance, because capital requirements for such mortgages are lower. Moreover, data from the Office of Thrift Supervision, the regulator of the savings association industry, indicate that only about 5 percent of the stock of all mortgages held by these institutions had an LTV higher than 80 percent and no private mortgage insurance. Reasonable adjustments to these data indicate that perhaps only as many as 12 percent of the home purchase originations might be in this category. As discussed in the main text, variations in this LTV distribution did not alter our conclusions. 
We also changed the VA risk-sharing arrangement to allocate more risk to the VA and changed the loan-to-value distributions for the FHA and the VA to reflect their reported LTV distributions. These changes raised the FHA's share about 2 percentage points and the VA's share about 1 percentage point.
All other institutions lost less than 1 percentage point of their market share. Thus, we conclude that our results are robust to reasonable changes in the assumptions and parameters that underlie our measures of credit risk. 